\title{
Seasonal Quality Assessment of Agricultural Soils along the Bank of Tungan Kawo Dam, Kontagora, Nigeria
}

\author{
Musa Sabo Abdullahi1 ${ }^{*}$, Adamu Uzairu1, Oluwole Joshua Okunola², \\ Muhammad Lawal Balarabe ${ }^{3}$ \\ ${ }^{1}$ Department of Chemistry, Ahmadu Bello University, Zaria, Nigeria \\ ${ }^{2}$ Department of Applied Chemistry, Federal University, Dutsin-Ma, Nigeria \\ ${ }^{3}$ Department of Biological Sciences, Ahmadu Bello University, Zaria, Nigeria \\ Email: "saboms@yahoo.com
}

Received 30 May 2016; accepted 14 August 2016; published 17 August 2016

Copyright (C) 2016 by authors and Scientific Research Publishing Inc.

This work is licensed under the Creative Commons Attribution International License (CC BY).

http://creativecommons.org/licenses/by/4.0/

(c) (i) Open Access

\begin{abstract}
This research work studies the impacts of irrigation and other agricultural practices on the soil along the bank of Tungan Kawo dam. The experimental analysis evaluates the soil physicochemical parameters and metal ( $\mathrm{Cd}, \mathrm{Cu}, \mathrm{Cr}, \mathrm{Ni}, \mathrm{Fe}, \mathrm{Mn}, \mathrm{Pb}$ and $\mathrm{Zn}$ ) concentrations using sequential extractions. The physicochemical parameters of the soils across the sites indicated values reported for less polluted soils. Also, analysis of total metals in the soils indicated lower concentration of all metals evaluated than recommended standard limits with exception of $\mathrm{Cd}$. The results of sequential extraction of heavy metal in soil sample indicated that all metals were mainly associated with the residual, Fe-MnO and organic bound fractions. The residual fraction has the maximum concentration of metals especially in cool and dry season for $\mathrm{Cr}, \mathrm{Cu}, \mathrm{Ni}, \mathrm{Pb}$ and $\mathrm{Zn}$, whereas only a small fraction of all the heavy metal is extracted in water soluble, exchangeable and carbonate bound fractions. It indicates that the bioavailability index is low. Hence, mobility of the heavy metals by the surrounding plants grown on the soils is low.
\end{abstract}

\section{Keywords}

Metals, Soils, Sequential, Contamination

\section{Introduction}

Pollution of the environment is an important problem in human's life that leads to a miserable condition. Envi-

*Corresponding author.

How to cite this paper: Abdullahi, M.S., Uzairu, A., Okunola, O.J. and Balarabe, M.L. (2016) Seasonal Quality Assessment of Agricultural Soils along the Bank of Tungan Kawo Dam, Kontagora, Nigeria. Journal of Agricultural Chemistry and Environment, 5, 132-151. http://dx.doi.org/10.4236/jacen.2016.53015 
ronment usually affected include: air, soil, water and vegetations which have direct effect on human life. The soil being the repository of all pollutants is most affected because soil is used for vegetation of edible plants and plants are taken in as part of our food. Soil is a very important natural resource to man as it is a source of his life on this planet. Despite its importance, soil is often contaminated by human activities and this is reflected in the high horizontal and vertical variability brought about by the anthropogenic influence on soil formation and development [1].

A variety of human activities including municipal waste disposal, industrial emissions, and agricultural practices have left their impacts on soils in the form of elevated and high level of toxicants especially the heavy metals [2]. The concentration of heavy metals in soil and their impact on ecosystems can be influenced by many factors such as the parent rock, climate and anthropogenic activities [3]. Among the pollutants that persist and accumulate in the soils include: inorganic toxic compounds. The soil is thus becoming increasingly polluted with chemicals and other pollutants which can reach the food chain, surface water or ground water and ultimately be ingested by man [4].

In Northern Nigeria, fadama is a common agricultural practice mostly located within the banks around rivers, dams and other major water sources that stay throughout the year and are often used for irrigation activities covering but not limited to the irrigation of assorted vegetables and other root crops [5]-[7]. Fadama is a Hausa word meaning the seasonally flooded or floodable plains along major savannah rivers and/or depressions on the adjacent low terraces [8]. Fadama utilization has been a major feature of the agricultural, food, economic and demographic experience of the Nigerian dry belt. The rationale for resource utilization here hinges on the availability of valuable agricultural resources in a zone where rain fed agricultural prospects are poor due to the small and erratic nature of rainfall and endemicity of drought [9]. Of a particular threat to fadamaor lowland irrigation crops in dry land areas located along dams are effluents agricultural practice and households especially where there no industrial contributions which contaminate irrigation channels. Tungan Kawo dam irrigation scheme in Kontagora is not different from the foregone problems. From literature, no information is available on the quality assessment of the agricultural soils along the bank of Tungan Kawo dam, hence, imperative for this study. Therefore, the study aimed to elucidate the quality of the agricultural soil through the following objective; determination of physicochemical parameters, metal concentration based on their geochemical forms and confirmation of their risk to plants.

\section{Materials and Methods}

\subsection{Study Area}

The Tungan Kawo Dam is located State between latitude $10^{\circ} 21^{\prime \prime} 58.51^{\circ} \mathrm{N}-10^{\circ} 23^{\prime \prime} 28.50^{\circ} \mathrm{N}$ of the equator and between longitude $5^{\circ} 19^{\prime \prime} 29.23^{\circ} \mathrm{E}-5^{\circ} 20 " 59.23^{\circ} \mathrm{E}$ in Tungan Kawo village, northwest of Kontagora, $7 \mathrm{~km}$ along Kontagora-Yauri road in Kontagora Local Government Area of Niger State. The dam has a catchments area of $143 \mathrm{~km}^{2}$ with a total storage capacity of $17.7 \mathrm{M}$ Cubic meters, $20 \mathrm{~m}$ high and dam crest length of $1000 \mathrm{~m}$. The dam was commission in May 1991. It is the largest source of water supply in Kontagora Township. The people of Tungan Kawo and its environs are predominantly farmers and have remained so for years. In this area, vegetables are irrigated with dam water and all kinds of available waste and polluted waters. Similarly, to enhance the yield of these vegetables, fertilizers and manures are occasionally added to the soil [10].

\subsection{Sampling}

The farmland was divided into five sampling plots as shown in Figure 1 and soil samples were collected within the rooting depth $(0-15 \mathrm{~cm})$ during when crops are harvested across the seasons. A total of fifteen (15) samples were collected from the five (5) sampling plots with the aid of a stainless bottom grab. The content of the grab was emptied into a black polythene bag [11] at each location, labelled and taken to the laboratory for processing/pre-treatment and analysis. Each sampling site comprises of three (3) samples composites to form a core for the site. Samples were collected on a seasonal basis between February 2012 and September 2013 as follows:

\footnotetext{
Seasons

Cool and dry season: December-February

Hot and dry season: March-May

Warm and wet season: June-August

Warm and dry season: September-November
} 


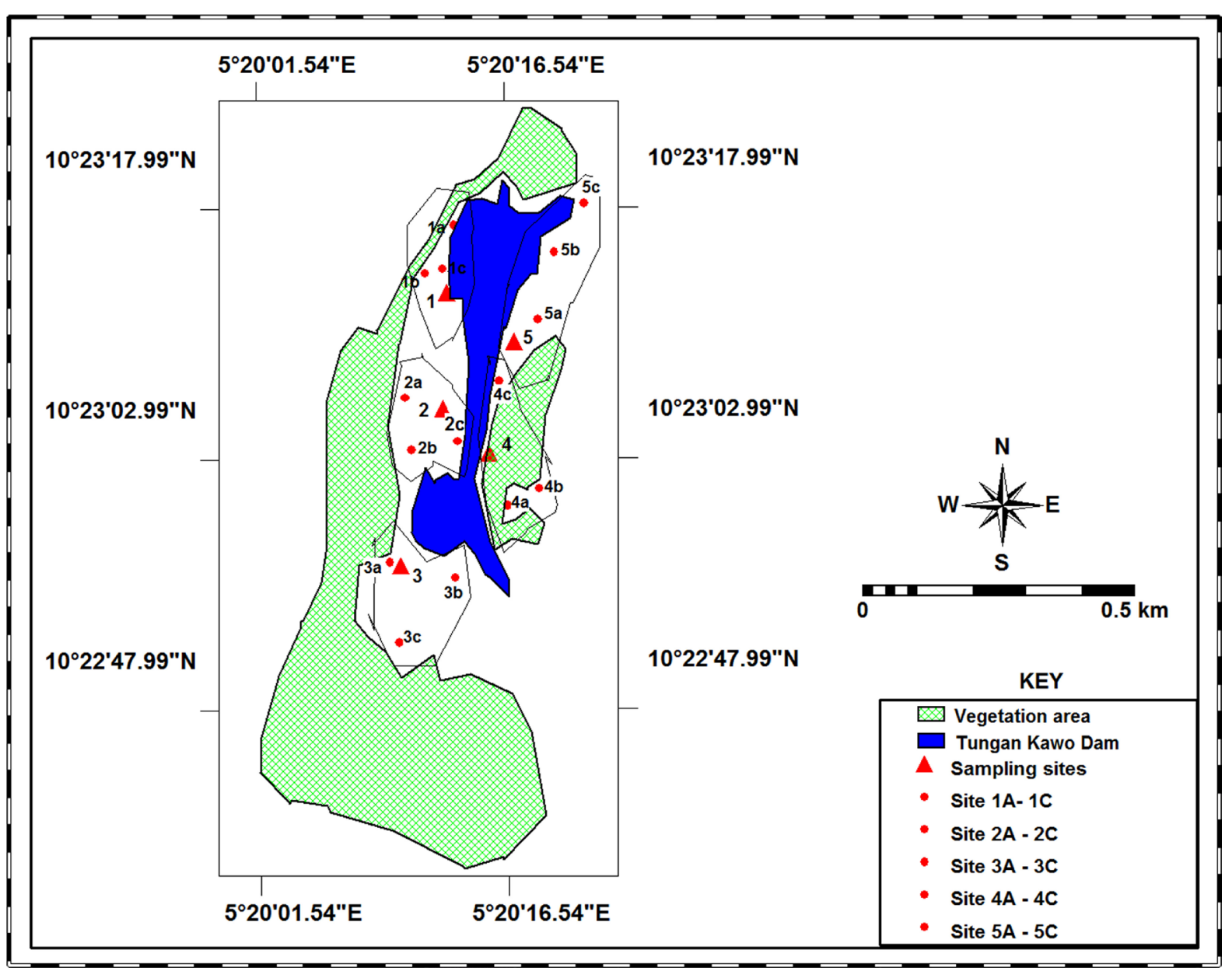

Source: Adapted and Modified from Europa technologies Google Earth Image, 2010

Figure 1. Tungan Kawo dam showing sampling sites and vegetation areas.

\subsection{Sample Pre-Treatment}

Soil samples for metal analysis were allowed to air-dried. Dry soils were ground into fine powder and homogenized using an acid-washed clean mortar and pestle and sieved to give $200 \mu \mathrm{m}$ particle size. They were then stored in desiccators to attain constant weight before being stored in air-tight plastic bottles. All metallic determination from soil samples was based on the fine particles obtained.

\subsection{Sequential Extraction}

Sequential extraction was carried out on the principle of selective extraction proposed by [12]. This method modified the conventional method developed by [13]. The modified method determines fractionation of heavy metals into six (6) geochemical fractions. $1.0 \mathrm{~g}$ of the homogenized sample was weighed into a conical flask and appropriate extractants were added and the $\mathrm{pH}$ of solution matrix was adjusted following a standard literature procedure according to [12]. The extract from the six stages of extractions were separately stored in a plastic vials prior to AAS analysis. The total concentrations of each metal were calculated as sum of the six fractions from the metal. Samples were analysed in triplicate. Sample treatment, extraction and subsequent analytical determinations were performed in a clean laboratory.

Quality control test was performed on soil and plant samples in order to validate the experimental procedures. This was done by spiking the pre-digested soil and plant samples with multielement metal standard solution $(0.5$ $\mathrm{mgL}^{-1}$ of $\mathrm{Cd}$ and $\mathrm{Cr}$ and $5 \mathrm{mgL}^{-1}$ for $\mathrm{Cu}, \mathrm{Fe}, \mathrm{Mn}, \mathrm{Ni}, \mathrm{Pb}$ and $\mathrm{Zn}$ ). The percentage recovery showed that $90 \%$ $95 \%$ of the spiked metals were recovered, indication of reliability of the results obtained. 


\subsection{Method Validation}

The efficiency of the digestion method was validated by a spiking experiment as described in the preceding chapter. The percentage recoveries of metals ranged from $99.0-108.0$ in pepper and $90.0-100.0$ in soils. The pattern of recovery efficiency in both pepper and soil were found to follow the decreasing order, $\mathrm{Cd}>\mathrm{Pb}>\mathrm{Ni}>$ $\mathrm{Mn}>\mathrm{Cu}>\mathrm{Zn}>\mathrm{Cr}$ and $\mathrm{Pb}>\mathrm{Mn}>\mathrm{Cd}>\mathrm{Zn}>\mathrm{Cu}>\mathrm{Ni}>\mathrm{Cr}$, respectively. However, high recoveries above $90 \%$ in this study could imply that the procedures used for treatment and analysis of sample is efficient.

\subsection{Physicochemical Parameters}

The $\mathrm{pH}$ and electrical conductivity of sediment samples was measured with sediment: water ratio 1:2 using $\mathrm{pH}$ and electrical conductivity meters as described by [14], organic carbon was determined by the method of [15], cation exchangeable capacity (CEC) was determined by [14], particle size distribution was determined by the hydrometer method as described by [16]. Also, extractable nitrate $\left(\mathrm{NO}_{3}^{-}\right)$, chloride $\left(\mathrm{Cl}^{-}\right)$, sulphate $\left(\mathrm{SO}_{4}^{2-}\right)$ and available phosphate $\left(\mathrm{PO}_{4}^{3-}\right)$ were determined by methods described by [17].

\section{Results and Discussion}

\subsection{Physicochemical Parameters}

The results of variation in physicochemical parameters from the study and control area in the four seasons are presented in Tables 1-4. The results of the pH for study site range from 5.77 (site 5) - 7.17 (site 1), 6.40 (sites 2 and 3) - 6.62 (site 1), 9.00 (site 4) - 10.23 (site 2), and 7.37 (site 3) - 7.49 (site 2) for cool and dry season, hot and dry season, warm and wet season, and warm and dry season respectively. For the control site, the $\mathrm{pH}$ fraction was 7.50, 6.20, 6.20 and 6.50 in the same order of seasons. $\mathrm{pH}$ in $\mathrm{CaCl}_{2 \text { (aq) }}$ for the study site showed 5.10 (site 3) - 5.27 (site 1), 5.27 (site 1) - 5.50 (site 3), 6.20 (site 5) - 6.67 (site 2) and 6.30 (sites 1 and 4 ) - 6.50 (site 3) for cool and dry season, hot and dry season, warm and wet season, and warm and dry season respectively. Also, for the control site, the $\mathrm{pH}$ in $\mathrm{CaCl}_{2(\mathrm{aq})}$ was found to be 6.50, 5.10, 5.10 and 5.10 across the seasons in the

Table 1. Physico-chemical parameters of soil samples during cool and dry season.

\begin{tabular}{|c|c|c|c|c|c|c|c|c|c|c|}
\hline Site & $\mathbf{p H}$ & $\mathbf{p H} \mathrm{CaCl}_{2}$ & $\begin{array}{c}\text { ECE } \\
(\mu \mathrm{S} / \mathrm{cm})\end{array}$ & OM (\%) & TN (\%) & $\begin{array}{c}\mathrm{NO}_{3}^{-} \\
(\mathrm{mg} / \mathrm{L})\end{array}$ & $\underset{(\mathrm{mg} / \mathbf{1 0 0 g})}{\text { AP }}$ & $\begin{array}{c}\mathrm{SO}_{4}^{2-} \\
(\mathrm{mg} / \mathrm{L})\end{array}$ & $\underset{(\mathrm{mg} / \mathrm{L})}{\mathrm{Cl}^{-}}$ & $\begin{array}{c}\text { CEC } \\
(\mathrm{Cmol} / \mathrm{kg})\end{array}$ \\
\hline 1 & $7.17 \pm 0.06$ & $5.27 \pm 0.06$ & $0.05 \pm 0.00$ & $0.78 \pm 0.01$ & $0.05 \pm 0.00$ & $0.01 \pm 0.00$ & $7.81 \pm 0.06$ & $8.50 \pm 0.05$ & $0.46 \pm 0.04$ & $5.37 \pm 0.06$ \\
\hline 2 & $6.67 \pm 0.06$ & $5.17 \pm 0.06$ & $0.03 \pm 0.01$ & $0.52 \pm 0.01$ & $0.04 \pm 0.00$ & $0.01 \pm 0.00$ & $13.13 \pm 0.01$ & $15.70 \pm 0.10$ & $0.34 \pm 0.01$ & $9.20 \pm 0.10$ \\
\hline 3 & $6.30 \pm 0.10$ & $5.10 \pm 0.10$ & $0.01 \pm 0.00$ & $0.75 \pm 0.01$ & $0.05 \pm 0.00$ & $0.01 \pm 0.00$ & $7.82 \pm 0.12$ & $13.29 \pm 0.01$ & $0.25 \pm 0.01$ & $8.40 \pm 0.10$ \\
\hline 4 & $5.80 \pm 0.10$ & $5.20 \pm 0.10$ & $1.31 \pm 0.09$ & $0.78 \pm 0.01$ & $0.08 \pm 0.01$ & $0.01 \pm 0.00$ & $8.74 \pm 0.04$ & $13.80 \pm 0.10$ & $0.45 \pm 0.02$ & $5.17 \pm 0.15$ \\
\hline 5 & $5.77 \pm 0.15$ & $5.20 \pm 0.10$ & $1.30 \pm 0.10$ & $0.65 \pm 0.02$ & $0.05 \pm 0.00$ & $0.01 \pm 0.00$ & $9.31 \pm 0.45$ & $8.52 \pm 0.08$ & $0.25 \pm 0.01$ & $5.70 \pm 0.10$ \\
\hline Control & $7.50 \pm 0.10$ & $6.50 \pm 0.10$ & $0.05 \pm 0.01$ & $2.35 \pm 0.05$ & $0.18 \pm 0.00$ & $0.01 \pm 0.00$ & $136.40 \pm 0.10$ & $15.07 \pm 0.02$ & $2.23 \pm 0.06$ & $10.13 \pm 0.06$ \\
\hline
\end{tabular}

EC: Electrical Conductivity; OM: Organic Matter; TN: Total Nitrogen; AP: Available Phosphorus; S: Sulphur; $\mathrm{Cl}^{-}$: Chloride; CEC: Cation Exchange Capacity.

Table 2. Physico-chemical parameters of soil samples during hot and dry season.

\begin{tabular}{|c|c|c|c|c|c|c|c|c|c|c|}
\hline Site & $\mathbf{p H}$ & $\mathbf{p H} \mathrm{CaCl}_{2}$ & $\begin{array}{c}\mathrm{ECE} \\
(\mu \mathrm{S} / \mathrm{cm})\end{array}$ & OM (\%) & TN (\%) & $\begin{array}{c}\mathrm{NO}_{3}^{-} \\
(\mathrm{mg} / \mathrm{L})\end{array}$ & $\underset{(\mathrm{mg} / \mathbf{1 0 0 g})}{\mathrm{AP}}$ & $\begin{array}{c}\mathrm{SO}_{4}^{2-} \\
(\mathrm{mg} / \mathrm{L})\end{array}$ & $\begin{array}{c}\mathrm{Cl}^{-} \\
(\mathrm{mg} / \mathrm{L})\end{array}$ & $\begin{array}{c}\mathrm{CEC} \\
(\mathrm{Cmol} / \mathrm{kg})\end{array}$ \\
\hline 1 & $6.62 \pm 0.03$ & $5.27 \pm 0.06$ & $0.10 \pm 0.00$ & $1.00 \pm 0.00$ & $0.05 \pm 0.00$ & $0.02 \pm 0.00$ & $7.03 \pm 0.06$ & $9.06 \pm 0.00$ & $0.80 \pm 0.00$ & $8.40 \pm 0.00$ \\
\hline 2 & $6.40 \pm 0.00$ & $5.40 \pm 0.00$ & $0.05 \pm 0.01$ & $1.60 \pm 0.00$ & $0.08 \pm 0.01$ & $0.01 \pm 0.00$ & $7.00 \pm 0.00$ & $20.53 \pm 0.01$ & $0.70 \pm 0.00$ & $7.83 \pm 0.06$ \\
\hline 3 & $6.40 \pm 0.00$ & $5.50 \pm 0.00$ & $0.07 \pm 0.01$ & $0.87 \pm 0.01$ & $0.08 \pm 0.00$ & $0.01 \pm 0.00$ & $7.07 \pm 0.06$ & $9.65 \pm 0.01$ & $0.57 \pm 0.06$ & $8.60 \pm 0.00$ \\
\hline 4 & $6.50 \pm 0.00$ & $5.30 \pm 0.00$ & $0.06 \pm 0.01$ & $1.49 \pm 0.03$ & $0.08 \pm 0.00$ & $0.01 \pm 0.00$ & $7.07 \pm 0.12$ & $9.77 \pm 0.01$ & $0.57 \pm 0.06$ & $8.57 \pm 0.12$ \\
\hline 5 & $6.42 \pm 0.03$ & $5.37 \pm 0.06$ & $0.05 \pm 0.01$ & $0.97 \pm 0.01$ & $0.06 \pm 0.00$ & $0.01 \pm 0.00$ & $7.17 \pm 0.15$ & $10.23 \pm 0.01$ & $0.67 \pm 0.06$ & $8.63 \pm 0.06$ \\
\hline Control & $6.20 \pm 0.00$ & $5.10 \pm 0.00$ & $0.10 \pm 0.00$ & $1.14 \pm 0.00$ & $0.06 \pm 0.00$ & $0.01 \pm 0.00$ & $7.10 \pm 0.10$ & $9.84 \pm 0.07$ & $0.50 \pm 0.00$ & $6.20 \pm 0.00$ \\
\hline
\end{tabular}

EC: Electrical Conductivity; OM: Organic Matter; TN: Total Nitrogen; AP: Available Phosphorus; S: Sulphur; $\mathrm{Cl}^{-}$: Chloride; $\mathrm{CEC}$ : Cation Exchange Capacity. 
Table 3. Physico-chemical parameters of soil samples during warm and wet season.

\begin{tabular}{|c|c|c|c|c|c|c|c|c|c|c|}
\hline Site & pH & $\mathbf{p} \mathbf{H}_{\mathrm{CaCl}_{2}}$ & $\begin{array}{c}\text { ECE } \\
(\mu \mathrm{S} / \mathbf{c m})\end{array}$ & OM (\%) & TN (\%) & $\begin{array}{c}\mathrm{NO}_{3}^{-} \\
(\mathrm{mg} / \mathrm{L})\end{array}$ & $\underset{(\mathrm{mg} / \mathbf{1 0 0 g})}{\text { AP }}$ & $\begin{array}{c}\mathrm{SO}_{4}^{2-} \\
(\mathrm{mg} / \mathrm{L})\end{array}$ & $\begin{array}{c}\mathrm{Cl}^{-} \\
(\mathrm{mg} / \mathrm{L})\end{array}$ & $\begin{array}{c}\text { CEC } \\
(\mathrm{Cmol} / \mathrm{kg})\end{array}$ \\
\hline 1 & $9.72 \pm 0.08$ & $6.37 \pm 0.06$ & $0.30 \pm 0.00$ & $2.10 \pm 0.00$ & $0.07 \pm 0.00$ & $1.75 \pm 0.01$ & $7.77 \pm 0.06$ & $15.46 \pm 0.01$ & $0.97 \pm 0.01$ & $9.63 \pm 0.06$ \\
\hline 2 & $10.23 \pm 0.38$ & $6.67 \pm 0.38$ & $0.07 \pm 0.01$ & $1.92 \pm 0.01$ & $0.08 \pm 0.00$ & $1.05 \pm 0.01$ & $8.07 \pm 0.15$ & $20.53 \pm 0.01$ & $0.90 \pm 0.06$ & $10.43 \pm 0.04$ \\
\hline 3 & $9.87 \pm 0.38$ & $6.50 \pm 0.00$ & $0.08 \pm 0.00$ & $1.87 \pm 0.01$ & $0.09 \pm 0.00$ & $1.07 \pm 0.01$ & $7.80 \pm 0.10$ & $13.58 \pm 0.11$ & $1.46 \pm 0.10$ & $9.62 \pm 0.01$ \\
\hline 4 & $9.00 \pm 0.46$ & $6.63 \pm 0.49$ & $0.07 \pm 0.00$ & $1.86 \pm 0.06$ & $0.09 \pm 0.00$ & $1.06 \pm 0.01$ & $8.33 \pm 0.06$ & $13.10 \pm 0.59$ & $0.95 \pm 0.00$ & $9.75 \pm 0.01$ \\
\hline 5 & $9.63 \pm 0.15$ & $6.20 \pm 0.36$ & $0.08 \pm 0.00$ & $1.97 \pm 0.01$ & $0.09 \pm 0.00$ & $1.07 \pm 0.01$ & $7.80 \pm 0.00$ & $10.90 \pm 1.15$ & $0.96 \pm 0.01$ & $8.90 \pm 0.11$ \\
\hline Control & $6.20 \pm 0.00$ & $5.10 \pm 0.00$ & $0.10 \pm 0.00$ & $1.14 \pm 0.00$ & $0.06 \pm 0.00$ & $1.02 \pm 0.00$ & $5.17 \pm 0.06$ & $9.84 \pm 0.01$ & $0.40 \pm 0.00$ & $5.17 \pm 0.06$ \\
\hline
\end{tabular}

Table 4. Physico-chemical parameters of soil samples during warm and dry season.

\begin{tabular}{|c|c|c|c|c|c|c|c|c|c|c|}
\hline Site & pH & $\mathbf{p} \mathbf{H}_{\mathrm{CaCl}_{2}}$ & $\begin{array}{c}\text { ECE } \\
(\mu \mathrm{S} / \mathrm{cm})\end{array}$ & OM (\%) & TN (\%) & $\begin{array}{c}\mathrm{NO}_{3}^{-} \\
(\mathrm{mg} / \mathrm{L})\end{array}$ & $\underset{(\mathrm{mg} / \mathbf{1 0 0 g})}{\mathrm{AP}}$ & $\begin{array}{c}\mathrm{SO}_{4}^{2-} \\
(\mathrm{mg} / \mathrm{L})\end{array}$ & $\begin{array}{c}\mathrm{Cl}^{-} \\
(\mathrm{mg} / \mathrm{L})\end{array}$ & $\begin{array}{c}\text { CEC } \\
(\mathrm{Cmol} / \mathrm{kg})\end{array}$ \\
\hline 1 & $7.40 \pm 0.18$ & $6.30 \pm 0.10$ & $0.15 \pm 0.00$ & $1.53 \pm 0.01$ & $0.07 \pm 0.01$ & $1.17 \pm 0.00$ & $29.17 \pm 7.96$ & $9.06 \pm 0.00$ & $0.80 \pm 0.00$ & $8.83 \pm 0.12$ \\
\hline 2 & $7.49 \pm 0.04$ & $6.40 \pm 0.00$ & $0.11 \pm 0.05$ & $1.62 \pm 0.01$ & $0.08 \pm 0.00$ & $1.11 \pm 0.00$ & $6.63 \pm 0.12$ & $11.53 \pm 0.01$ & $0.70 \pm 0.00$ & $8.73 \pm 0.15$ \\
\hline 3 & $7.37 \pm 0.06$ & $6.50 \pm 0.00$ & $0.09 \pm 0.01$ & $0.97 \pm 0.01$ & $0.09 \pm 0.00$ & $1.11 \pm 0.00$ & $7.23 \pm 0.06$ & $9.65 \pm 0.01$ & $0.57 \pm 0.06$ & $8.80 \pm 0.10$ \\
\hline 4 & $7.48 \pm 0.05$ & $6.30 \pm 0.00$ & $0.09 \pm 0.00$ & $1.52 \pm 0.01$ & $0.08 \pm 0.00$ & $1.11 \pm 0.00$ & $7.33 \pm 0.12$ & $9.77 \pm 0.01$ & $0.57 \pm 0.06$ & $8.73 \pm 0.06$ \\
\hline 5 & $7.44 \pm 0.01$ & $6.37 \pm 0.06$ & $0.09 \pm 0.00$ & $0.98 \pm 0.01$ & $0.07 \pm 0.00$ & $1.11 \pm 0.00$ & $7.30 \pm 0.00$ & $10.23 \pm 0.01$ & $0.67 \pm 0.06$ & $8.70 \pm 0.10$ \\
\hline Control & $6.50 \pm 0.00$ & $5.10 \pm 0.00$ & $0.10 \pm 0.00$ & $1.14 \pm 0.00$ & $0.06 \pm 0.00$ & $0.01 \pm 0.00$ & $5.20 \pm 0.00$ & $9.70 \pm 0.05$ & $0.50 \pm 0.00$ & $5.50 \pm 0.00$ \\
\hline
\end{tabular}

EC: Electrical Conductivity; OM: Organic Matter; TN: Total Nitrogen; AP: Available Phosphorus; S: Sulphur; $\mathrm{Cl}^{-}$: Chloride; CEC: Cation Exchange Capacity.

same order as the study sites. Analysis of variation among the study sites across the seasons showed significant differences $(\mathrm{p}<0.05)$. The varying sources of effluent discharge into the dam across the seasons could be a possible reason. Comparing the $\mathrm{pH}$ of study and control sites, $\mathrm{pH}$ at the control site is alkaline across the seasons.Within $\mathrm{pH}$ range of 5.8 - 6.5, acidity is present (apparently from hydroxyl-Al and organic functional groups, ordinarily hydronium, in amounts sufficient to affect acid-sensitive crops [18]). This could imply high mobility of metals within these sites to other environmental compartment. For $\mathrm{pH}$ at $6.5-8.0$ the soil is essentially fully base saturated, with large amounts of exchangeable Ca and $\mathrm{Mg}$ [19]. The $\mathrm{pH}$ values recorded in the study areas are similar to $\mathrm{pH}$ values 5.5 to 6.3 and 5.40 to 7.60 reported by [20] and [9], respectively for some other Nigerian irrigated soils.

The electrical conductivity (EC) across the seasons, cool and dry, hot and dry, warm and wet, and warm and dry showed the range: 0.01 (site 3) - 1.31 (site 4), 0.05 (site 2 and 5) - 0.10 (site 1), 0.07 (site 2 and 4) - 0.30 (site 1), and 0.09 (site 3, 4 and 5) $-0.15 \mu \mathrm{S} / \mathrm{cm}$ (site 1) for the seasons respectively, 0.05, 0.10, 0.10 and 0.10 $\mu \mathrm{S} / \mathrm{cm}$ were the EC values for the control site across the seasons in the same order. There were significant differences $(\mathrm{p}<0.05)$ in EC among the various sites. Highest values of EC were recorded at site 4 during cool and dry season. Analysis of variation also indicated that mean values of EC did vary between and within seasons, and did show seasonal pattern. Generally, the values reported in this study are lower than $3-80 \mu \mathrm{S} / \mathrm{cm}$ reported in Bakori Dam irrigation soils [20]. By comparison, [21] classified ECE of soils (in $\mathrm{dSm}^{-1}$ ) as: non-saline $<2$; moderately saline 2 - 8; very saline 8 - 16; extremely saline $>16$. Across the seasons $\mathrm{EC}<1$ which indicated no acute problems with soil salinity.

Seasonal variation in percentage organic matter $(\mathrm{OM})$ and the variations between sampling sites were observed. The OM varied between 0.52 (site 2) - 0.78 (site 1 and 4), 0.87 (site 3) - 1.60 (site 2), 1.86 (site 4) - 2.10 (site 1), and 0.97 (site 3) - 1.62\% (site 2) for cool and dry season, hot and dry season, warm and wet season, and warm and dry season, respectively for study sites. However, 2.35, 1.14, 1.14 and 1.14 were observed for the control site across the seasons. Analysis of variation among the study sites across the seasons showed significant differences $(\mathrm{p}<0.05)$. Higher OM content in control site compare to study site (cool and dry season) could be due decomposition of weed plants over a long period as compare to study area where these are not found. The range of $\mathrm{OM}$ in this study is lower than $2.04 \%$ to $2.20 \%$ reported by [9]. However, the values are typically low and characteristic of savanna soils because of rapid decomposition of plant and animal residues added to soil 
[22]. This implies that the soil organic matter contains humic materials with low complex functional groups, which have the ability to complex metals thereby retaining them in the topsoil [23]. The more organic matter is present in soil, the more functional groups available for complexation with the metals, hence, the more the retention [24]. The organic matter of soils in the present study indicated low retention of metals, thereby making them available for plant uptake.

The total nitrogen (TN) in the soil varied between 0.04 (site 2) - $0.08 \%$ (site 4) for cool and dry season, 0.05 (site 1) $-0.08 \%$ (site 2, 3 and 4) for hot and dry season, 0.07 (site 1) - $0.09 \%$ (site 3, 4 and 5) for warm and wet season, and 0.07 (site 1 and 5) - 0.09\% (site 3) during warm and dry season. Across the seasons highest TN was recorded at site $3(0.09 \% \mathrm{~d})$ during warm and dry season. For the control site, TN (\%) were observed to be 0.18 , 0.06, 0.06 and 0.06 for cool and dry season, hot and dry season, warm and wet season, and warm and dry season, respectively. There were no significant differences $(p>0.05)$ in EC among the various sites. Analysis of variation also indicated that mean values of EC did vary between and within seasons, and did show seasonal pattern. Across the seasons, there is a general increase in TN in all sites, this suggest increase in content of nitrogen in the soils. The range of TN in this study is lower than the range of 0.5 to $21.9 \%$ reported in Nigeria [20].

The concentration of nitrate $\left(\mathrm{NO}_{3}^{-}\right)$in the soil samples fluctuated between $0.01 \mathrm{mg} / \mathrm{l}$ (at all sites), 0.01 (site 2, 3, 4 and 5) - $0.02 \mathrm{mg} / \mathrm{l}$ (site 1), 1.05 (site 2) - $1.75 \mathrm{mg} / \mathrm{l}$ (site 1), and 1.11 (site 2, 3, 4 and 5) - $1.17 \mathrm{mg} / \mathrm{l}$ (site 1) during the cool and dry season, hot and dry season, warm and wet season, and warm and dry season, respectively. Also, across the season highest \% OM was recorded for site $1(1.75 \mathrm{mg} / \mathrm{l})$ during warm and wet season. For control site, $\mathrm{NO}_{3}^{-}$values were $0.01,0.01,1.02$ and $0.01 \mathrm{mg} / \mathrm{l}$ for cool and dry, hot and dry, warm and wet, and warm and dry seasons, respectively. Analysis of variance among the various sampling sites showed significant differences $(\mathrm{p}<0.05)$. Generally, highest concentrations of $\mathrm{NO}_{3}^{-}$in soil were revealed during warm and dry season. Nitrate is among one of the macro nutrients necessary for plant growth [25]. The magnitude of nitrate in leaching will depend on the amount of nitrates in the soil, amount and time of rainfall, infiltration and percolation rates and also the water-holding capacity of the soil [26]. The amount of nitrate in the study area is higher than the control area, this suggest input of fertilizer used during irrigation responsible for the increase in the study sites. This also corroborate with the increase in the coefficient of nitrate during hot and dry, warm and wet, and warm and dry seasons. Also, from the results in the cool and dry season, there seems to be no clear trend in the level of nitrate across the sites. However, there is a gradual increase in nitrate across the sites down the warm and dry season. The values in this study is lower than range of $0.2-4.62 \mathrm{mg} / \mathrm{L}$ reported by [20].

The available phosphorus (AP) across the seasons, cool and dry, hot and dry, warm and wet, and warm and dry showed the range: 7.81 (site 1) - $13.13 \mathrm{mg} / \mathrm{L}$ (site 2), 7.00 (site 2) - $7.17 \mathrm{mg} / \mathrm{L}$ (site 5), 7.77 (site 1) - 8.33 $\mathrm{mg} / \mathrm{L}$ (site 4), and 6.63 (site 2) - $29.71 \mathrm{mg} / \mathrm{L}$ (site 1) for the seasons respectively, 136.40, 7.10, 5.17 and 5.20 $\mathrm{mg} / \mathrm{L}$ were the AP values for the control site across the seasons in the same order. There were significant differences $(p=0.021)$ in AP among the various sites. Highest values of AP were recorded at site 4 during cool and dry season. Analysis of variation also indicated that values of AP vary $(\mathrm{p}<0.05)$ between the seasons. Similar to nitrogen, phosphorus is an essential elements classified as macronutrient because of the relatively large amounts of phosphorus required by plants [25]. Phosphorus is among the nutrient added to the soils through the application of fertilizer, hence, comparison of AP between study and control sites showed that control site has high level of phosphorus, this suggest possible input of phosphate from other anthropogenic sources. Across the seasons, there is no clear trend in the level of AP in the sites, although highest range of $6.63-29.17 \mathrm{mg} / 100 \mathrm{~g}$ was observed in warm and dry season. This could be related to strong positive correlation between the AP concentration and $\mathrm{pH}$ and organic matter. Similar relationship was also reported by [25]. However, the concentration of AP was higher than $0.3-0.6 \mathrm{mg} / 100 \mathrm{~g}$ reported in related study in Nigeria [20].

Sulphate ( $\mathrm{SO}_{4}^{2-}$ ) varied between 8.50 (site 1) - $15.70 \mathrm{mg} / \mathrm{l}$ (site 2) in cool and dry season, 9.60 (site 1) - 20.53 $\mathrm{mg} / \mathrm{l}$ (site 2) in hot and dry season, 10.90 (site 5) - $20.53 \mathrm{mg} / \mathrm{l}$ (site 2) in warm and wet season, and 9.60 (site 1) $11.53 \mathrm{mg} / \mathrm{l}$ (site 2) in warm and dry season. Highest concentration of sulphate was recorded in warm and wet season. Analysis of variation across the seasons showed significant difference $(\mathrm{p}<0.05)$ in the values. For control site, $\mathrm{SO}_{4}^{2-}$ values were 15.07, 9.84, 9.84 and $9.70 \mathrm{mg} / \mathrm{l}$ for cool and dry, hot and dry, warm and wet, and warm and dry seasons, respectively. The profile of sulphate $\left(\mathrm{SO}_{4}^{2-}\right)$ content of the soils of the study areas decreases in the warm and dry season $(9.60-11.53 \mathrm{mg} / \mathrm{l})$. The decrease in sulphate content of the soils could result from the parent materials, high leaching rates, crop removal and low level of atmospheric sulphur-bearing air [27]. Retention of sulphate in soils is highly dependent on $\mathrm{pH}$ and mineralogy and this is supported with strong positive correlation between $\mathrm{SO}_{4}^{2-}, \mathrm{pH}$ and organic matter. Also the fate of sulphate in the soil is influenced by 
many chemical, biological and physical factors and the ability of the soil to adsorb the sulphates occurs above a $\mathrm{pH}$ of 6.5 but adsorption increases as $\mathrm{pH}$ decreases [28], this was not observed in this study. In comparison to other studies range of values across the seasons was lower than $13.7-94.4 \mathrm{mg} / \mathrm{L}$ reported in literature [20]. Fluctuation in amount of $\mathrm{SO}_{4}^{2-}$ across the season may occur as a result of leaching, mineralization of organic sulphur and uptake by plants [25].

Chloride ( $\mathrm{Cl}^{-}$) fluctuated between 0.25 (site 3 and 5) - $0.46 \mathrm{mg} / \mathrm{l}$ (site 1), 0.57 (site 3 and 4) - $0.80 \mathrm{mg} / \mathrm{l}$ (site 1), 0.90 (site 2) - $1.46 \mathrm{mg} / \mathrm{l}$ (site 3), and 0.57 (site 3 and 4) - $0.80 \mathrm{mg} / \mathrm{l}$ (site 1) in during the cool and dry season, hot and dry season, warm and wet season, and warm and dry season, respectively. Analysis of variance showed that there were significant differences $(\mathrm{p}<0.05)$ in the values of chloride recorded among the various sampling sites across the seasons. Again there was no clear seasonal pattern observed. For control site, $\mathrm{Cl}^{-}$values were 2.23, $0.50,0.40$ and $0.50 \mathrm{mg} / \mathrm{l}$ for cool and dry, hot and dry, warm and wet, and warm and dry seasons, respectively. According to [25], $\mathrm{Cl}^{-}$content of the soil is not an intrinsic property of the soil, but is a result of soil management, because of the its mobility in the soil and the fact that it moves with the water in the soil. This could explain the increase in the amount of $\mathrm{Cl}^{-}$during the warm and wet season $(0.90-1.46 \mathrm{mg} / \mathrm{l})$ with a slight decrease $(0.57-0.80 \mathrm{mg} / \mathrm{l})$ in warm and dry season-a season after rains. This occur as a result of the fact that $\mathrm{Cl}^{-}$is not adsorbed on the soil particles at neutral and alkaline $\mathrm{pH}$ values [29] which is the $\mathrm{pH}$ prevalence during the warm and wet, and warm and dry seasons. The $\mathrm{Cl}^{-}$concentrations in the control sites are higher than the study sites in cool and dry season, this could occur as a result of anthropogenic inputs. The results recorded in this study are lower compare to $1.2-40.8 \mathrm{mg} / \mathrm{l}$ reported in Bakori [20].

CEC also varied between 5.17 (site 4) - $9.20 \mathrm{Cmolkg}^{-1}$ (site 2), 7.83 (site 2) - $8.63 \mathrm{Cmolkg}^{-1}$ (site 5), 8.90 (site 5) - $10.43 \mathrm{Cmolkg}^{-1}$ (site 2), and 8.70 (site 5) - 8.83 (site 1) for cool and dry, hot and dry, warm and wet, and warm and dry seasons, respectively. Significantly, there were variations $(\mathrm{p}<0.05)$ among sites across seasons with lowest mean value of CEC recorded in the Cool and Dry Season and the highest mean value recorded in the warm and wet season. For control site, CEC values were 10.13, 6.20, 5.17 and $5.50 \mathrm{Cmolkg}^{-1}$ for cool and dry, hot and dry, warm and wet, and warm and dry seasons, respectively. Similar, to percentage organic matter content, highest CEC were obtained during warm and wet season across all sites. Analysis of variation showed significant differences $(p<0.05)$ in the value of CEC recorded among the sites across the seasons. Comparing the study and control sites, high values were obtained in study sites with exception in cool and dry season. The CEC of soils is related to the nature and quality of clay and organic matter. Hence, high \% organic carbon from these sites could be responsible for the CEC. According to [9], CEC of soil is more greatly influenced by organic matter than by the concentration of clays, hence CEC tends to be higher in the study sites than the control sites. For savanna soils dominated by low-activity clay and low organic matter, the CEC is quite low. According to [22] and Wild (1975), CEC of savanna soils is more greatly influenced by organic matter than by the concentration of clays, hence CEC tends to be higher in the studied soils.

Multivariate correlation analysis between various soil physicochemical parameters across the seasons is presented in Tables 5-8. Some of the parameters were found to bear statistically significant correlation with each

Table 5. Correlation matrix among metals in soils physicochemical parameters during cool and dry season.

\begin{tabular}{|c|c|c|c|c|c|c|c|c|c|c|}
\hline Parameter & pH & $\mathbf{p} \mathbf{H}_{\mathrm{CaCl}_{2}}$ & ECE & OM & TN & $\mathrm{NO}_{3}^{-}$ & AP & $\mathrm{SO}_{4}^{2-}$ & $\mathrm{Cl}^{-}$ & CEC \\
\hline pH & 1.000 & & & & & & & & & \\
\hline $\mathbf{p H} \mathrm{CaCl}_{2}$ & $0.684^{* *}$ & 1.000 & & & & & & & & \\
\hline ECE & $-0.791^{* *}$ & -0.277 & 1.000 & & & & & & & \\
\hline OM & $0.652^{* *}$ & $0.978^{* *}$ & -0.281 & 1.000 & & & & & & \\
\hline TN & $0.504^{*}$ & $0.937^{* *}$ & -0.100 & $0.973^{* *}$ & 1.000 & & & & & \\
\hline $\mathrm{NO}_{3}^{-}$ & 0.144 & 0.011 & -0.008 & 0.105 & 0.108 & 1.000 & & & & \\
\hline AP & $0.662^{* *}$ & $0.983^{* *}$ & -0.310 & $0.983^{* *}$ & $0.945^{* *}$ & -0.020 & 1.000 & & & \\
\hline $\mathrm{SO}_{4}^{2-}$ & 0.200 & 0.335 & -0.321 & 0.341 & 0.376 & $-0.500^{*}$ & 0.417 & 1.000 & & \\
\hline $\mathrm{Cl}^{-}$ & $0.689^{* *}$ & $0.986^{* *}$ & -0.302 & $0.988^{* *}$ & $0.959^{* *}$ & 0.051 & $0.991^{* *}$ & 0.394 & 1.000 & \\
\hline CEC & $0.551^{*}$ & $0.564^{*}$ & $-0.675^{* *}$ & $0.550^{*}$ & 0.444 & -0.446 & $0.648^{* *}$ & $0.735^{* *}$ & $0.581^{*}$ & 1.000 \\
\hline
\end{tabular}

${ }^{* *}$ Correlation is significant at the 0.01 level (2-tailed). ${ }^{*}$ Correlation is significant at the 0.05 level (2-tailed). 
Table 6. Correlation matrix among metals in soils physicochemical parameters during hot and dry season.

\begin{tabular}{|c|c|c|c|c|c|c|c|c|c|c|}
\hline Parameter & pH & $\mathbf{p} \mathbf{H}_{\mathrm{CaCl}_{2}}$ & ECE & $\mathbf{O M}$ & TN & $\mathrm{NO}_{3}^{-}$ & AP & $\mathrm{SO}_{4}^{2-}$ & $\mathrm{Cl}^{-}$ & CEC \\
\hline $\mathbf{P h}$ & 1 & & & & & & & & & \\
\hline $\mathbf{p} \mathbf{H}_{\mathrm{CaCl}_{2}}$ & 0.298 & 1 & & & & & & & & \\
\hline ECE & -0.077 & $-0.683^{* *}$ & 1 & & & & & & & \\
\hline $\mathbf{O M}$ & -0.016 & -0.094 & -0.380 & 1 & & & & & & \\
\hline TN & 0.004 & $0.553^{*}$ & $-0.657^{* *}$ & $0.484^{*}$ & 1 & & & & & \\
\hline $\mathrm{NO}_{3}^{-}$ & $0.697^{* *}$ & -0.190 & $0.595^{* *}$ & -0.294 & $-0.561^{*}$ & 1 & & & & \\
\hline AP & -0.184 & -0.089 & -0.033 & -0.287 & -0.190 & -0.177 & 1 & & & \\
\hline $\mathrm{SO}_{4}^{2-}$ & -0.128 & 0.278 & -0.440 & $0.698^{* *}$ & 0.323 & -0.275 & -0.309 & 1 & & \\
\hline $\mathrm{Cl}^{-}$ & $0.697^{* *}$ & 0.235 & 0.000 & -0.019 & -0.345 & $0.715^{* *}$ & -0.189 & 0.239 & 1 & \\
\hline CEC & $0.774^{* *}$ & $0.738^{* *}$ & $-0.553^{*}$ & -0.153 & 0.316 & 0.200 & 0.000 & -0.114 & 0.442 & 1 \\
\hline
\end{tabular}

${ }^{* *}$ Correlation is significant at the 0.01 level (2-tailed). ${ }^{*}$ Correlation is significant at the 0.05 level (2-tailed).

Table 7. Correlation matrix among metals in soils physicochemical parameters during wet and warm season.

\begin{tabular}{|c|c|c|c|c|c|c|c|c|c|c|}
\hline Parameter & pH & $\mathbf{p} \mathbf{H}_{\mathrm{CaCl}_{2}}$ & ECE & OM & TN & $\mathrm{NO}_{3}^{-}$ & AP & $\mathrm{SO}_{4}^{2-}$ & $\mathrm{Cl}^{-}$ & CEC \\
\hline pH & 1 & & & & & & & & & \\
\hline $\mathrm{CaCl}_{2}$ & $0.801^{* *}$ & 1 & & & & & & & & \\
\hline ECE & 0.090 & -0.016 & 1 & & & & & & & \\
\hline OM & $0.923^{* *}$ & $0.794^{* *}$ & 0.314 & 1 & & & & & & \\
\hline TN & $0.709^{* *}$ & $0.732^{* *}$ & -0.422 & $0.650^{* *}$ & 1 & & & & & \\
\hline $\mathrm{NO}_{3}^{-}$ & 0.254 & 0.141 & $0.984^{* *}$ & $0.472^{*}$ & -0.275 & 1 & & & & \\
\hline AP & $0.899^{* *}$ & $0.900^{* *}$ & -0.002 & $0.916^{* *}$ & $0.833^{* *}$ & 0.172 & 1 & & & \\
\hline $\mathrm{SO}_{4}^{2-}$ & $0.650^{* *}$ & $0.570^{*}$ & 0.104 & $0.519^{*}$ & 0.160 & 0.211 & $0.537^{*}$ & 1 & & \\
\hline $\mathrm{Cl}^{-}$ & $0.771^{* *}$ & $0.677^{* *}$ & -0.031 & $0.696^{* *}$ & $0.693^{* *}$ & 0.091 & $0.718^{* *}$ & 0.268 & 1 & \\
\hline CEC & $0.943^{* *}$ & $0.906^{* *}$ & 0.062 & $0.919^{* *}$ & $0.726^{* *}$ & 0.235 & $0.970^{* *}$ & $0.697^{* *}$ & $0.736^{* *}$ & 1 \\
\hline
\end{tabular}

${ }^{* *}$ Correlation is significant at the 0.01 level (2-tailed). ${ }^{*}$ Correlation is significant at the 0.05 level (2-tailed).

Table 8. Correlation matrix among metals in soils physicochemical parameters during September-November.

\begin{tabular}{|c|c|c|c|c|c|c|c|c|c|c|}
\hline Parameter & pH & $\mathbf{p H}_{\mathrm{CaCl}_{2}}$ & ECE & OM & TN & $\mathrm{NO}_{3}^{-}$ & AP & $\mathrm{SO}_{4}^{2-}$ & $\mathrm{Cl}^{-}$ & CEC \\
\hline Ph & 1 & & & & & & & & & \\
\hline $\mathbf{p} \mathbf{H}_{\mathrm{CaCl} 2}$ & $0.960^{* *}$ & 1 & & & & & & & & \\
\hline ECE & 0.061 & 0.027 & 1 & & & & & & & \\
\hline $\mathbf{O M}$ & 0.316 & 0.172 & $0.481^{*}$ & 1 & & & & & & \\
\hline TN & $0.682^{* *}$ & $0.704^{* *}$ & -0.245 & 0.247 & 1 & & & & & \\
\hline $\mathrm{NO}_{3}^{-}$ & $0.972^{* *}$ & $0.981^{* *}$ & 0.124 & 0.277 & $0.647^{* *}$ & 1 & & & & \\
\hline AP & 0.261 & 0.116 & 0.395 & 0.204 & -0.051 & 0.187 & 1 & & & \\
\hline $\mathrm{SO}_{4}^{2-}$ & 0.241 & 0.203 & -0.170 & 0.249 & 0.398 & 0.132 & -0.296 & 1 & & \\
\hline $\mathrm{Cl}^{-}$ & $0.558^{*}$ & $0.519^{*}$ & $0.612^{* *}$ & 0.455 & 0.000 & $0.601^{* *}$ & 0.405 & 0.063 & 1 & \\
\hline CEC & $0.970^{* *}$ & $0.981^{* *}$ & 0.082 & 0.261 & $0.678^{* *}$ & $0.997^{* *}$ & 0.183 & 0.145 & $0.571^{*}$ & 1 \\
\hline
\end{tabular}

other indicating close association of the parameters. In the cool and dry season (Table 7), for example, data showed high significant positive correlation between the OM: $\mathrm{pH}, \mathrm{TN}$ : $\mathrm{pH}$ and $\mathrm{OM}, \mathrm{AP}: \mathrm{pH}, \mathrm{OM}$ and $\mathrm{TN}, \mathrm{Cl}^{-}$: $\mathrm{pH}, \mathrm{OM}, \mathrm{TN}$ and $\mathrm{AP}$, and CEC: $\mathrm{pH}, \mathrm{OM}, \mathrm{AP}, \mathrm{SO}_{4}^{2-}$ and $\mathrm{Cl}^{-}(\mathrm{p}<0.05)$. On the contrary in hot and dry season 
(Table 8), significant positive correlations $(\mathrm{p}<0.05)$ were observed between $\mathrm{TN}: \mathrm{pH}, \quad \mathrm{NO}_{3}^{-}$: $\mathrm{pH}, \mathrm{ECE}, \mathrm{SO}_{4}^{2-}$ : $\mathrm{OM}, \mathrm{Cl}^{-}: \mathrm{pH}$ and $\mathrm{NO}_{3}^{-}$, and ECE: $\mathrm{pH}$. Similarly, in warm and wet season (Table 9), significant positive correlations ( $\mathrm{p}<0.01$ ) were observed between: $\mathrm{OM}$ : $\mathrm{pH}, \mathrm{TN}$ : $\mathrm{pH}$ and $\mathrm{OM}, \mathrm{NO}_{3}^{-}$: ECE, OM, AP: $\mathrm{pH}, \mathrm{OM}$ and TN, $\mathrm{SO}_{4}^{2-}: \mathrm{pH}, \mathrm{OM}$ and $\mathrm{AP}, \mathrm{Cl}^{-}: \mathrm{pH}, \mathrm{OM}, \mathrm{TN}$ and $\mathrm{AP}$, and CEC: $\mathrm{pH}, \mathrm{OM}, \mathrm{TN}, \mathrm{AP}, \mathrm{SO}_{4}^{2-}$ and $\mathrm{Cl}^{-}$. In warm and dry season (Table 10), similar relationships were observed between the parameters as recorded in cool and dry season with few exceptions. On the other hand, negative correlation was also observed between CEC: ECE ( $<<$ $0.01)$ in cool and dry season, ECE: pH and CEC, and TN: ECE in hot and dry season $(\mathrm{p}<0.01)$. Significant negative correlations among the physicochemical parameters imply that increase in level of one of the parameter would increase the other.

\subsection{Total Metal Concentration in Soil}

The total metals concentration of namely $\mathrm{Cd}, \mathrm{Cr}, \mathrm{Cu}, \mathrm{Fe}, \mathrm{Ni}, \mathrm{Pb}$ and $\mathrm{Znin}$ soils samples from the sites studied are presented in Tables 9-12. In each case the presented value is a mean observed in three determinations. Analysis of variance (ANOVA) revealed significant differences $(\mathrm{p}<0.05)$ in the contents of all the heavy metals across seasons with exception of $\mathrm{Cr}$ and $\mathrm{Zn}$. The concentrations across the seasons varied to a greater extent among the samples: 2.82 (site 4 and 5) - 2.86 (site 1), 1.00 (site 5) - 1.21 (site 1), 3.32 (site 4) - 3.38 (site 1) and 3.32 (site 1) - $4.31 \mathrm{mgkg}^{-1}$ (site 5) for Cd, 52.87 (site 2) - 107.83 (site 5), 29.58 (site 5) - 32.57 (site 1), 24.44 (site 5) - 25.73 (site 1) and 27.94 (site 3) - $29.61 \mathrm{mgkg}^{-1}$ (site 1) for Cr, 48.01 (site 4) - 48.65 (site 5), 2.22 (site 4) - 2.42 (site 2), 5.69 (site 5) - 5.81 (site 1) and 6.88 (site 2) - $7.40 \mathrm{mgkg}^{-1}$ (site 5) for $\mathrm{Cu}, 699.74$ (site 5) - 701.72 (site 1), 3156.82 (site 4) - 3162.18 (site 1), 3821.57 (site 3) - 7540.01 (site 4) and 3076.76 (site 4) - 3160.51 $\mathrm{mgkg}^{-1}$ (site 2) for Fe, 7.51 (site 4) - 7.65 (site 1), 23.82 (site 5) - 26.27 (site 1), 29.19 (site 4) - 29.56 (site 1)

Table 9. Concentration (mg/kg) of metals in soils during cool and dry season.

\begin{tabular}{ccccccccc}
\hline Site & $\mathbf{C d}$ & $\mathbf{C r}$ & $\mathbf{C u}$ & $\mathbf{F e}$ & $\mathbf{M n}$ & $\mathbf{N i}$ & $\mathbf{P b}$ \\
\hline $\mathbf{1}$ & $2.86 \pm 0.06$ & $53.68 \pm 0.47$ & $48.15 \pm 0.13$ & $701.72 \pm 0.49$ & $7.65 \pm 0.01$ & $137.52 \pm 0.53$ & $164.45 \pm 0.21$ & $272.95 \pm 0.72$ \\
$\mathbf{2}$ & $2.79 \pm 0.04$ & $52.87 \pm 1.00$ & $48.64 \pm 0.75$ & $699.94 \pm 1.78$ & $7.59 \pm 0.08$ & $137.60 \pm 1.23$ & $162.89 \pm 0.92$ & $271.82 \pm 0.63$ \\
$\mathbf{3}$ & $2.77 \pm 0.10$ & $53.17 \pm 0.60$ & $49.14 \pm 1.18$ & $700.61 \pm 1.83$ & $7.58 \pm 0.09$ & $137.45 \pm 1.04$ & $163.03 \pm 1.62$ & $273.32 \pm 0.73$ \\
$\mathbf{4}$ & $2.82 \pm 0.08$ & $53.33 \pm 0.82$ & $48.01 \pm 0.61$ & $700.94 \pm 2.46$ & $7.51 \pm 0.06$ & $136.39 \pm 1.38$ & $163.48 \pm 1.35$ & $272.30 \pm 1.47$ \\
$\mathbf{5}$ & $2.82 \pm 0.05$ & $107.83 \pm 3.87$ & $48.65 \pm 1.02$ & $699.74 \pm 2.03$ & $7.59 \pm 0.10$ & $136.83 \pm 0.92$ & $163.32 \pm 0.90$ & $271.30 \pm 1.63$ \\
Control & $3.63 \pm 0.21$ & $47.48 \pm 0.49$ & $44.04 \pm 1.62$ & $650.2 \pm 11.22$ & $6.87 \pm 0.23$ & $123.95 \pm 2.27$ & $152.59 \pm 3.49$ & $258.68 \pm 4.33$ \\
\hline
\end{tabular}

Table 10. Concentration (mg/kg) of metals in soils during hot and dry season.

\begin{tabular}{ccccccccc}
\hline Site & $\mathbf{C d}$ & $\mathbf{C r}$ & $\mathbf{C u}$ & $\mathbf{F e}$ & $\mathbf{M n}$ & $\mathbf{N i}$ & $\mathbf{P b}$ \\
\hline $\mathbf{1}$ & $1.21 \pm 0.02$ & $32.57 \pm 0.30$ & $2.51 \pm 0.01$ & $3162.18 \pm 0.19$ & $26.27 \pm 0.15$ & $15.45 \pm 0.08$ & $12.85 \pm 0.07$ & $227.52 \pm 0.04$ \\
$\mathbf{2}$ & $1.17 \pm 0.01$ & $31.20 \pm 0.15$ & $2.42 \pm 0.07$ & $3160.42 \pm 0.23$ & $24.59 \pm 0.63$ & $15.04 \pm 0.09$ & $12.18 \pm 0.07$ & $226.46 \pm 1.11$ \\
$\mathbf{3}$ & $1.09 \pm 0.02$ & $31.66 \pm 0.16$ & $2.24 \pm 0.04$ & $3158.85 \pm 0.30$ & $24.53 \pm 0.66$ & $14.61 \pm 0.28$ & $12.48 \pm 0.13$ & $225.41 \pm 1.24$ \\
$\mathbf{4}$ & $1.05 \pm 0.04$ & $30.42 \pm 0.04$ & $2.22 \pm 0.10$ & $3156.82 \pm 0.12$ & $24.70 \pm 0.74$ & $17.29 \pm 5.20$ & $12.34 \pm 0.03$ & $225.50 \pm 1.06$ \\
$\mathbf{5}$ & $1.00 \pm 0.01$ & $29.58 \pm 0.02$ & $2.29 \pm 0.06$ & $3158.68 \pm 0.21$ & $23.82 \pm 0.10$ & $14.94 \pm 0.05$ & $12.16 \pm 0.09$ & $225.15 \pm 0.64$ \\
Control & $1.69 \pm 0.14$ & $13.82 \pm 0.04$ & $1.66 \pm 0.14$ & $2008.72 \pm 0.76$ & $11.37 \pm 0.10$ & $10.19 \pm 0.27$ & $0.18 \pm 0.01$ & $30.27 \pm 0.30$ \\
\hline
\end{tabular}

Table 11. Concentration (mg/kg) of metals in soils during warm and wet season.

\begin{tabular}{ccccccccc}
\hline Site & $\mathbf{C d}$ & $\mathbf{C r}$ & $\mathbf{C u}$ & $\mathbf{F e}$ & $\mathbf{M n}$ & $\mathbf{N i}$ & $\mathbf{P b}$ \\
\hline $\mathbf{1}$ & $3.38 \pm 0.01$ & $25.73 \pm 0.10$ & $5.81 \pm 0.01$ & $4100.17 \pm 1.46$ & $29.56 \pm 0.10$ & $17.54 \pm 0.02$ & $12.76 \pm 0.05$ & $344.47 \pm 0.64$ \\
$\mathbf{2}$ & $3.37 \pm 0.01$ & $25.61 \pm 0.09$ & $5.74 \pm 0.02$ & $4099.76 \pm 1.11$ & $29.55 \pm 0.16$ & $17.48 \pm 0.09$ & $12.70 \pm 0.04$ & $343.62 \pm 1.42$ \\
$\mathbf{3}$ & $3.37 \pm 0.01$ & $25.56 \pm 0.11$ & $5.72 \pm 0.02$ & $3821.57 \pm 11.80$ & $29.41 \pm 0.22$ & $17.49 \pm 0.06$ & $12.67 \pm 0.04$ & $343.35 \pm 0.65$ \\
$\mathbf{4}$ & $3.32 \pm 0.03$ & $25.53 \pm 0.09$ & $5.75 \pm 0.04$ & $7540.01 \pm 62.82$ & $29.19 \pm 0.47$ & $17.47 \pm 0.06$ & $12.53 \pm 0.13$ & $343.10 \pm 1.20$ \\
$\mathbf{5}$ & $3.33 \pm 0.02$ & $25.44 \pm 0.12$ & $5.69 \pm 0.06$ & $4094.58 \pm 5.90$ & $29.37 \pm 0.18$ & $17.05 \pm 0.36$ & $12.58 \pm 0.08$ & $342.69 \pm 0.17$ \\
Control & $2.18 \pm 0.14$ & $13.82 \pm 0.04$ & $1.37 \pm 0.14$ & $3186.02 \pm 0.82$ & $14.74 \pm 0.09$ & $9.71 \pm 0.22$ & $2.41 \pm 0.14$ & $34.26 \pm 0.46$ \\
\hline
\end{tabular}


and 28.24 (site 3) - $29.03 \mathrm{mgkg}^{-1}$ (site 1) for Mn, and 136.39 (site 4) - 137.60 (site 2), 14.61 (site 3) - 17.29 (site 4), 17.05 (site 5) - 17.54 (site 1) and 16.96 (site 3 and 4) - $43.21 \mathrm{mgkg}^{-1}$ (site 1)for Ni, 162.89 (site 2) - 164.45 (site 1), 12.16 (site 5) - 12.85 (site 1), 12.53 (site 4) - 12.76 (site 1) and 12.94 (site 3) - $13.74 \mathrm{mgkg}^{-1}$ (site 1) for $\mathrm{Pb}$, and 271.30 (site 5) - 273.32 (site 3), 225.15 (site 5) - 227.52 (site 1), 342.69 (site 5) - 344.47 (site 1) and 319.82 (site 4) - $321.41 \mathrm{mgkg}^{-1}$ (site 1) for Zn in cool and dry, hot and dry, warm and wet, and warm and dry seasons, respectively.

Irrespective of sampling site, the distribution of total metals in the soil samples generally followed the order: $\mathrm{Fe}>\mathrm{Zn}>\mathrm{Cr}>\mathrm{Mn}>\mathrm{Pb}>\mathrm{Ni}>\mathrm{Cu}>\mathrm{Cd}$. Highest levels of $\mathrm{Cd}$, $\mathrm{Cr}$ and $\mathrm{Cu}$ were found at site 5, while highest concentrations of $\mathrm{Fe}, \mathrm{Mn}, \mathrm{Pb}$ and $\mathrm{Zn}$, and $\mathrm{Ni}$ were found at site 1 and 2, respectively. Also in all the sites, highest concentration of $\mathrm{Cr}, \mathrm{Cu}, \mathrm{Ni}$ and $\mathrm{Pb}$ was recorded in cool and dry season, $\mathrm{Fe}, \mathrm{Mn}$ and $\mathrm{Zn}$ was recorded in warm and wet season, and Cd was recorded in warm and dry season.

Correlation analysis as shown in Tables 13-16 indicates significant positive correlation $(\mathrm{p}<0.05)$ between $\mathrm{Pb}$ and $\mathrm{Cd}$ (cool and dry season), $\mathrm{Cd}$ : $\mathrm{Cr}$ and $\mathrm{Zn}, \mathrm{Cu}: \mathrm{Zn}$ and Fe, and $\mathrm{Mn}: \mathrm{Pb}$ and $\mathrm{Zn}$ (hot and dry season), $\mathrm{Cu}: \mathrm{Cr}$, $\mathrm{Cd}$ : $\mathrm{Mn}$ and $\mathrm{Pb}$ (warm and wet season) and $\mathrm{Mn}$ and $\mathrm{Fe}$ (warm and dry season). Positive correlation of metals indicate common source of metals. As shown in the results, after the rainy season (Warm and Dry Season), there was a decrease in levels of metals across at all the sites with exception of Fe, Mn and Zn. The differences observed after rains for Fe, Mn and Zn could represent a more recent accumulation of these metals after the rainy season.

From the result as presented for the metals (Tables 9-12), it is observed that the concentrations of Cd and $\mathrm{Zn}$ in the soil during warm and wet, and warm and dry seasons across the sites is above $1-3$ and $50-300 \mathrm{mg} / \mathrm{kg}$ recommended for these metals in soil by European Standards . The values in this study is higher than 0.27 - 1.47 and $32.30-98.50 \mathrm{mg} / \mathrm{kg}$ reported in soils [9]. A study by [30] on heavy metal content of agricultural soils recorded lower levels of $\mathrm{Cd}$ in the soil ranging from $0.150-0.880 \mathrm{mg} / \mathrm{kg}$, hence, concentration above EU limits could reflects the influence of human activity. The concentrations of $\mathrm{Cr}, \mathrm{Cu}, \mathrm{Mn}, \mathrm{Ni}$ and $\mathrm{Pb}$ were within the ranging from 104.30 - 230.00, 58.30 - 207.50, 51.67 - 97.50, 39.30 - 99.50 and 60.00 - $143.30 \mathrm{mg} / \mathrm{kg}$ recorded for $\mathrm{Cr}, \mathrm{Cu}, \mathrm{Mn}, \mathrm{Ni}$ and $\mathrm{Pb}$, respectively in irrigated soils [9]. Similarly, the values recorded for these metals are below 400, 140, 300, 50, $300 \mathrm{mg} / \mathrm{kg}$ the maximum permissible levels for soils recommended by [31] and EU for the metals.

Table 12. Concentration $(\mathrm{mg} / \mathrm{kg})$ of metals in soils during warm and dry season.

\begin{tabular}{ccccccccc}
\hline & $\mathbf{C d}$ & $\mathbf{C r}$ & $\mathbf{C u}$ & $\mathbf{F e}$ & $\mathbf{M n}$ & $\mathbf{N i}$ & $\mathbf{P b}$ & $\mathbf{Z n}$ \\
\hline $\mathbf{1}$ & $3.32 \pm 0.11$ & $28.35 \pm 1.48$ & $6.93 \pm 0.40$ & $3202.89 \pm 5.49$ & $29.03 \pm 0.88$ & $43.21 \pm 1.28$ & $13.09 \pm 0.38$ & $321.41 \pm 2.08$ \\
$\mathbf{2}$ & $3.54 \pm 0.67$ & $29.61 \pm 1.30$ & $6.88 \pm 0.23$ & $3160.51 \pm 16.69$ & $28.94 \pm 1.15$ & $17.35 \pm 1.12$ & $13.09 \pm 0.38$ & $319.96 \pm 3.06$ \\
$\mathbf{3}$ & $3.65 \pm 0.38$ & $27.94 \pm 1.53$ & $7.34 \pm 0.39$ & $2543.87 \pm 74.42$ & $28.24 \pm 1.25$ & $16.96 \pm 0.96$ & $12.94 \pm 0.47$ & $319.87 \pm 2.98$ \\
$\mathbf{4}$ & $4.03 \pm 0.60$ & $28.35 \pm 2.19$ & $7.20 \pm 0.48$ & $3076.76 \pm 10.37$ & $28.68 \pm 1.07$ & $16.96 \pm 0.96$ & $12.98 \pm 0.70$ & $319.82 \pm 3.34$ \\
$\mathbf{5}$ & $4.31 \pm 0.65$ & $28.58 \pm 0.84$ & $7.40 \pm 0.60$ & $3117.73 \pm 5.29$ & $29.14 \pm 1.47$ & $17.64 \pm 0.80$ & $13.74 \pm 0.90$ & $320.73 \pm 2.32$ \\
Control & na & na & na & na & na & na & na & na \\
\hline
\end{tabular}

na: not available.

Table 13. Correlation matrix among metals in soils during cool and dry season.

\begin{tabular}{|c|c|c|c|c|c|c|c|c|}
\hline Parameter & Cd & $\mathrm{Cr}$ & $\mathrm{Cu}$ & $\mathbf{F e}$ & Mn & $\mathbf{N i}$ & $\mathbf{P b}$ & Zn \\
\hline $\mathrm{Cd}$ & 1.000 & & & & & & & \\
\hline $\mathrm{Cr}$ & 0.141 & 1.000 & & & & & & \\
\hline $\mathrm{Cu}$ & -0.802 & 0.157 & 1.000 & & & & & \\
\hline $\mathrm{Fe}$ & 0.584 & -0.586 & -0.537 & 1.000 & & & & \\
\hline Mn & 0.390 & 0.072 & 0.137 & 0.249 & 1.000 & & & \\
\hline $\mathrm{Ni}$ & -0.186 & -0.350 & 0.473 & 0.082 & 0.765 & 1.000 & & \\
\hline $\mathrm{Pb}$ & $0.919^{*}$ & -0.093 & -0.660 & 0.821 & 0.502 & 0.009 & 1.000 & \\
\hline $\mathrm{Zn}$ & -0.081 & -0.703 & 0.139 & 0.733 & 0.183 & 0.376 & 0.310 & 1.000 \\
\hline
\end{tabular}

*Correlation is significant at the 0.05 level (2-tailed). 
Table 14. Correlation matrix among metals in soils during hot and dry season.

\begin{tabular}{|c|c|c|c|c|c|c|c|c|}
\hline Parameter & Cd & $\mathrm{Cr}$ & $\mathrm{Cu}$ & Fe & Mn & $\mathbf{N i}$ & $\mathbf{P b}$ & Zn \\
\hline Cd & 1.000 & & & & & & & \\
\hline $\mathrm{Cr}$ & $0.887^{*}$ & 1.000 & & & & & & \\
\hline $\mathrm{Cu}$ & 0.850 & 0.629 & 1.000 & & & & & \\
\hline $\mathrm{Fe}$ & 0.843 & 0.728 & $0.950^{*}$ & 1.0000 & & & & \\
\hline Mn & 0.817 & 0.858 & 0.714 & 0.686 & 1.000 & & & \\
\hline $\mathbf{N i}$ & -0.169 & -0.202 & -0.271 & -0.506 & 0.165 & 1.000 & & \\
\hline $\mathbf{P b}$ & 0.621 & 0.842 & 0.499 & 0.576 & $0.912^{*}$ & 0.029 & 1.000 & \\
\hline $\mathrm{Zn}$ & $0.936^{*}$ & 0.797 & $0.935^{*}$ & 0.876 & $0.901^{*}$ & -0.043 & 0.696 & 1.000 \\
\hline
\end{tabular}

${ }^{*}$ Correlation is significant at the 0.05 level (2-tailed).

Table 15. Correlation matrix among metals in soils during warm and wet season.

\begin{tabular}{ccccccccc}
\hline Parameter & $\mathbf{C d}$ & $\mathbf{C r}$ & $\mathbf{C u}$ & $\mathbf{F e}$ & $\mathbf{M n}$ & $\mathbf{N i}$ & $\mathbf{P b}$ & $\mathbf{Z n}$ \\
$\mathbf{C d}$ & 1.000 & & & & & & \\
$\mathbf{C r}$ & 0.789 & 1.000 & & & & & & \\
$\mathbf{C u}$ & 0.492 & $0.920^{*}$ & 1.000 & & & & & \\
$\mathbf{F e}$ & -0.713 & -0.218 & 0.121 & 1.000 & & & & \\
$\mathbf{M n}$ & $0.890^{*}$ & 0.671 & 0.380 & -0.812 & 1.000 & & 1.000 & \\
$\mathbf{N i}$ & 0.570 & 0.783 & 0.733 & 0.157 & 0.251 & 0.502 & 1.000 \\
$\mathbf{P b}$ & $0.974^{* *}$ & 0.842 & 0.585 & -0.706 & $0.940^{*}$ & 0.000 \\
$\mathbf{Z n}$ & 0.802 & $0.995^{* *}$ & $0.912^{*}$ & -0.2760 & 0.703 & 0.726 & 0.866 & 1.000 \\
\hline
\end{tabular}

${ }^{*}$ Correlation is significant at the 0.05 level (2-tailed). ${ }^{* *}$ Correlation is significant at the 0.01 level (2-tailed).

Table 16. Correlation matrix among metals in soils during warm and dry season.

\begin{tabular}{|c|c|c|c|c|c|c|c|c|}
\hline Parameter & Cd & $\mathrm{Cr}$ & $\mathrm{Cu}$ & $\mathbf{F e}$ & Mn & $\mathbf{N i}$ & $\mathbf{P b}$ & Zn \\
\hline $\mathrm{Cd}$ & 1 & & & & & & & \\
\hline $\mathrm{Cr}$ & -0.117 & 1 & & & & & & \\
\hline $\mathrm{Cu}$ & 0.765 & -0.609 & 1 & & & & & \\
\hline $\mathrm{Fe}$ & 0.023 & 0.581 & -0.554 & 1 & & & & \\
\hline $\mathrm{Mn}$ & 0.147 & 0.530 & -0.342 & $0.913^{*}$ & 1 & & & \\
\hline $\mathrm{Ni}$ & -0.626 & -0.180 & -0.521 & 0.391 & 0.369 & 1 & & \\
\hline $\mathrm{Pb}$ & 0.657 & 0.155 & 0.417 & 0.364 & 0.673 & -0.111 & 1 & \\
\hline $\mathrm{Zn}$ & -0.238 & -0.124 & -0.230 & 0.498 & 0.652 & 0.858 & 0.412 & 1 \\
\hline
\end{tabular}

${ }^{*}$ Correlation is significant at the 0.05 level (2-tailed).

The distribution of heavy metals $\mathrm{Cd}, \mathrm{Cr}, \mathrm{Cu}, \mathrm{Fe}, \mathrm{Mn}, \mathrm{Ni}, \mathrm{Pb}$ and $\mathrm{Zn}$ in the six fractions (water soluble (FI) exchangeable (FII), carbonate bound (FIII), Fe-Mn oxide (FIV), organic bound (FV) and residual (FVI)) for all the samples are summarized in Tables 17-24. The results obtained showed that the amounts of heavy metals extracted from each fraction varied widely among the sites across seasons $(\mathrm{p}<0.05)$.

As observed in Table 17, fractions of Cd in the soil samples among the sites across the seasons showed the range; water soluble: $\mathrm{BDL}-0.47 \mathrm{mg} / \mathrm{kg}$ with the highest concentration at site 4 during cool and dry season, exchangeable: $0.02-0.75 \mathrm{mg} / \mathrm{kg}$ with the highest concentration at site 4 during warm and dry season, 0.06 - 0.99 , $0.36-0.94,0.17-0.98 \mathrm{mg} / \mathrm{kg}$ with the highest concentration at site 5 for organic bound, carbonate bound and Fe-MnO fractions during warm and dry season, the residual fraction ranged from $0.42-0.92 \mathrm{mg} / \mathrm{kg}$ with the highest concentration $0.92 \mathrm{mg} / \mathrm{kg}$ found at different sites across the seasons. As observed from the results high- 
Table 17. Chemical fractionation of $\mathrm{Cd}(\mathrm{mg} / \mathrm{kg})$ in soil samples of irrigation farmlands along Kawo dam.

\begin{tabular}{|c|c|c|c|c|c|c|c|}
\hline Site & Season & Water Soluble & Exchangeable & Organic Bound & Carbonate Bound & Fe-MnO & Residual \\
\hline \multirow{4}{*}{1} & Cool and dry & $0.46 \pm 0.03(15.95)$ & $0.28 \pm 0.01(9.90)$ & $0.44 \pm 0.00(15.37)$ & $0.42 \pm 0.01(14.55)$ & $0.35 \pm 0.01(12.11)$ & $0.92 \pm 0.00(32.13)$ \\
\hline & Hot and dry & $0.00 \pm 0.01(0.28)$ & $0.04 \pm 0.00$ & $0.07 \pm 0.00(6.16)$ & $0.42 \pm 0.01(35.10)$ & $0.24 \pm 0.01(20.18)$ & $0.42 \pm 0.00(35.21)$ \\
\hline & Warm and wet & $0.03 \pm 0.00(0.94)$ & $0.42 \pm 0.00(12.48)$ & $0.74 \pm 0.00(21.84)$ & $0.84 \pm 0.00(24.90)$ & $0.42 \pm 0.00(12.52)$ & $0.92 \pm 0.00(27.33)$ \\
\hline & Warm and dry & $0.06 \pm 0.00$ (1.79) & $0.65 \pm 0.01(19.41)$ & $0.85 \pm 0.01(25.48)$ & $0.66 \pm 0.02(19.96)$ & $0.51 \pm 0.03(15.29)$ & $0.60 \pm 0.04(18.07)$ \\
\hline \multirow{4}{*}{2} & Cool and dry & $0.43 \pm 0.01(15.55)$ & $0.28 \pm 0.01(10.05)$ & $0.43 \pm 0.01(15.31)$ & $0.41 \pm 0.01(14.59)$ & $0.33 \pm 0.01(11.72)$ & $0.91 \pm 0.01(32.78)$ \\
\hline & Hot and dry & $0.00 \pm 0.00(0.09)$ & $0.03 \pm 0.00(2.26)$ & $0.07 \pm 0.00(6.28)$ & $0.41 \pm 0.01(35.41)$ & $0.23 \pm 0.00(19.70)$ & $0.42 \pm 0.00(36.26)$ \\
\hline & Warm and wet & $0.03 \pm 0.00(1.00)$ & $0.42 \pm 0.00(12.31)$ & $0.74 \pm 0.00(21.86)$ & $0.84 \pm 0.00(24.93)$ & $0.42 \pm 0.00(12.50)$ & $0.92 \pm 0.00(27.40)$ \\
\hline & Warm and dry & $0.07 \pm 0.02(1.92)$ & $0.69 \pm 0.05(19.43)$ & $0.90 \pm 0.12(25.31)$ & $0.72 \pm 0.03(20.45)$ & $0.36 \pm 0.26(10.11)$ & $0.81 \pm 0.19(22.77)$ \\
\hline \multirow{4}{*}{3} & Cool and dry & $0.46 \pm 0.02(16.49)$ & $0.28 \pm 0.01(10.23)$ & $0.40 \pm 0.03(14.44)$ & $0.40 \pm 0.02(14.56)$ & $0.32 \pm 0.02(11.43)$ & $0.91 \pm 0.01$ \\
\hline & Hot and dry & $0.00 \pm 0.00(0.03)$ & $0.02 \pm 0.00$ & $0.07 \pm 0.00(6.38)$ & $0.36 \pm 0.01(32.84)$ & $0.22 \pm 0.01(19.95)$ & $0.42 \pm 0.00(38.82)$ \\
\hline & Warm and wet & $0.03 \pm 0.00(0.92)$ & $0.42 \pm 0.00(12.34)$ & $0.73 \pm 0.00(21.82)$ & $0.84 \pm 0.00(24.92)$ & $0.42 \pm 0.00(12.57)$ & $0.92 \pm 0.00(27.43)$ \\
\hline & Warm and dry & $0.10 \pm 0.05(2.71)$ & $0.74 \pm 0.01(20.26)$ & $0.89 \pm 0.03(24.27)$ & $0.61 \pm 0.06(16.61)$ & $0.55 \pm 0.04(14.96)$ & $0.77 \pm 0.20(21.20)$ \\
\hline \multirow{4}{*}{4} & Cool and dry & $0.47 \pm 0.01(16.69)$ & $0.28 \pm 0.01(10.06)$ & $0.41 \pm 0.02(14.67)$ & $0.40 \pm 0.03(14.20)$ & $0.33 \pm 0.01(11.83)$ & $0.92 \pm 0.01(32.54)$ \\
\hline & Hot and dry & $0.00 \pm 0.00(0.03)$ & $0.02 \pm 0.00$ (2.18) & $0.06 \pm 0.01(5.67)$ & $0.36 \pm 0.01(33.90)$ & $0.19 \pm 0.02(18.37)$ & $0.42 \pm 0.00(39.85)$ \\
\hline & Warm and wet & $0.03 \pm 0.00(0.93)$ & $0.42 \pm 0.00(12.68)$ & $0.70 \pm 0.01(20.95)$ & $0.84 \pm 0.00(25.25)$ & $0.41 \pm 0.01$ & $0.92 \pm 0.00(27.80)$ \\
\hline & Warm and dry & $0.11 \pm 0.06(2.72)$ & $0.75 \pm 0.02(18.52)$ & $0.80 \pm 0.04(19.94)$ & $0.68 \pm 0.02(16.81)$ & $0.94 \pm 0.22(23.33)$ & $0.75 \pm 0.24(18.69)$ \\
\hline \multirow{4}{*}{5} & Cool and dry & $0.44 \pm 0.01(15.48)$ & $0.28 \pm 0.00(9.93)$ & $0.43 \pm 0.01(15.25)$ & $0.41 \pm 0.01(14.66)$ & $0.34 \pm 0.02(12.17)$ & $0.92 \pm 0.01(32.51)$ \\
\hline & Hot and dry & $0.00 \pm 0.00(0.10)$ & $0.02 \pm 0.00(1.52)$ & $0.06 \pm 0.00(5.58)$ & $0.34 \pm 0.01(33.52)$ & $0.17 \pm 0.01(17.26)$ & $0.42 \pm 0.00(42.02)$ \\
\hline & Warm and wet & $0.03 \pm 0.00(0.90)$ & $0.42 \pm 0.00(12.47)$ & $0.72 \pm 0.00(21.65)$ & $0.84 \pm 0.00(25.08)$ & $0.41 \pm 0.01(12.34)$ & $0.92 \pm 0.00(27.56)$ \\
\hline & warm and dry & $0.10 \pm 0.07(2.26)$ & $0.65 \pm 0.08(15.12)$ & $0.99 \pm 0.12(22.87)$ & $0.94 \pm 0.17(21.81)$ & $0.98 \pm 0.12(22.69)$ & $0.66 \pm 0.08(15.25)$ \\
\hline \multirow{4}{*}{ Control } & Cool and dry & $0.20 \pm 0.00(5.50)$ & $0.90 \pm 0.02(24.77)$ & $0.74 \pm 0.08(20.46)$ & $0.43 \pm 0.02(11.74)$ & $0.45 \pm 0.08(12.48)$ & $0.91 \pm 0.01(25.05)$ \\
\hline & Hot and dry & $0.02 \pm 0.00(1.26)$ & $0.01 \pm 0.01(0.79)$ & $0.74 \pm 0.08(44.07)$ & $0.46 \pm 0.05(27.27)$ & $0.03 \pm 0.01(1.58)$ & $0.42 \pm 0.00(25.02)$ \\
\hline & Warm and wet & $0.02 \pm 0.00(0.98)$ & $0.01 \pm 0.01(0.61)$ & $0.74 \pm 0.08(34.04)$ & $0.46 \pm 0.05(21.07)$ & $0.03 \pm 0.01(1.22)$ & $0.92 \pm 0.00(42.09)$ \\
\hline & Warm and dry & na & na & na & na & na & na \\
\hline
\end{tabular}

Value in parenthesis () is the percentage fraction; na: not available.

Table 18. Chemical fractionation of $\mathrm{Cr}(\mathrm{mg} / \mathrm{kg})$ in soil samples of irrigation farmlands along Kawo dam.

\begin{tabular}{cccccccc}
\hline Site & Season & Water Soluble & Exchangeable & Organic Bound & Carbonate Bound & Fe-MnO \\
\hline & Cool and dry & $0.73 \pm 0.01(1.36)$ & $1.45 \pm 0.01(2.70)$ & $1.78 \pm 0.01(3.32)$ & $0.73 \pm 0.01(1.37)$ & $2.52 \pm 0.01(4.69)$ & $46.46 \pm 0.42(86.56)$ \\
& Hot and dry & $2.26 \pm 0.25(6.95)$ & $3.60 \pm 0.03(11.04)$ & $3.59 \pm 0.00(11.01)$ & $3.73 \pm 0.01(11.44)$ & $5.67 \pm 0.00(17.42)$ & $13.72 \pm 0.02(42.13)$ \\
& Warm and wet & $0.45 \pm 0.01(1.75)$ & $1.77 \pm 0.01(6.88)$ & $2.56 \pm 0.01(9.95)$ & $1.84 \pm 0.00(7.16)$ & $5.35 \pm 0.01(20.79)$ & $13.76 \pm 0.06(53.47)$ \\
& Warm and dry & $1.49 \pm 0.04(5.26)$ & $1.78 \pm 0.09(6.27)$ & $2.32 \pm 0.30(8.18)$ & $1.78 \pm 0.06(6.29)$ & $5.50 \pm 0.45(19.39)$ & $15.48 \pm 0.55(54.61)$ \\
& Cool and dry & $0.70 \pm 0.01(1.32)$ & $1.45 \pm 0.01(2.74)$ & $1.74 \pm 0.02(3.28)$ & $0.70 \pm 0.01(1.32)$ & $2.49 \pm 0.02(4.70)$ & $45.80 \pm 0.93(86.62)$ \\
& Hot and dry & $1.79 \pm 0.07(5.75)$ & $2.74 \pm 0.00(8.79)$ & $3.61 \pm 0.06(11.57)$ & $3.66 \pm 0.02(11.72)$ & $5.67 \pm 0.00(18.18)$ & $13.72 \pm 0.01(43.99)$ \\
& Warm and wet & $0.43 \pm 0.01(1.68)$ & $1.71 \pm 0.04(6.66)$ & $2.53 \pm 0.01(9.89)$ & $1.84 \pm 0.00(7.18)$ & $5.32 \pm 0.01(20.78)$ & $13.78 \pm 0.03(53.80)$ \\
& Warm and dry & $1.45 \pm 0.09(4.90)$ & $1.86 \pm 0.09(6.27)$ & $2.53 \pm 0.04(8.56)$ & $1.76 \pm 0.03(5.96)$ & $5.56 \pm 0.50(18.77)$ & $16.45 \pm 0.55(55.55)$ \\
& Cool and dry & $0.75 \pm 0.02(1.41)$ & $1.41 \pm 0.03(2.65)$ & $1.74 \pm 0.07(3.28)$ & $0.68 \pm 0.03(1.27)$ & $2.43 \pm 0.08(4.58)$ & $46.16 \pm 0.38(86.81)$ \\
& Hot and dry & $1.62 \pm 0.07(5.11)$ & $3.53 \pm 0.01(11.15)$ & $3.64 \pm 0.00(11.51)$ & $3.61 \pm 0.05(11.40)$ & $5.58 \pm 0.00(17.61)$ & $13.68 \pm 0.02(43.22)$ \\
& Warm and wet & $0.43 \pm 0.02(1.70)$ & $1.72 \pm 0.01(6.72)$ & $2.52 \pm 0.01(9.86)$ & $1.84 \pm 0.00(7.18)$ & $5.33 \pm 0.03(20.85)$ & $13.73 \pm 0.06(53.70)$ \\
& Warm and dry & $1.57 \pm 0.06(5.63)$ & $1.80 \pm 0.04(6.44)$ & $2.27 \pm 0.35(8.14)$ & $1.80 \pm 0.05(6.45)$ & $5.49 \pm 0.47(19.63)$ & $15.01 \pm 0.57(53.71)$ \\
\hline
\end{tabular}




\begin{tabular}{|c|c|c|c|c|c|c|c|}
\hline \multicolumn{8}{|c|}{ Continued } \\
\hline \multirow{3}{*}{4} & Cool and dry & $0.74 \pm 0.02(1.38)$ & $1.47 \pm 0.06(2.76)$ & $1.68 \pm 0.15(3.15)$ & $0.71 \pm 0.02$ & $2.38 \pm 0.14(4.46)$ & $46.35 \pm 0.44$ (86.91) \\
\hline & Hot and dry & $1.43 \pm 0.01(4.70)$ & $2.75 \pm 0.01(9.06)$ & $3.46 \pm 0.01$ (11.38) & $3.53 \pm 0.01$ (11.62) & $5.56 \pm 0.00(18.29)$ & $13.68 \pm 0.01(44.96)$ \\
\hline & Warm and wet & $0.44 \pm 0.01(1.74)$ & $1.69 \pm 0.02(6.63)$ & $2.52 \pm 0.01(9.87)$ & $1.83 \pm 0.00(7.18)$ & $5.32 \pm 0.02(20.82)$ & $13.72 \pm 0.04(53.75)$ \\
\hline & Warm and dry & $1.71 \pm 0.32(6.04)$ & $1.80 \pm 0.05(6.36)$ & $2.49 \pm 0.07$ (8.79) & $1.75 \pm 0.05(6.17)$ & $5.80 \pm 0.05(20.44)$ & $14.80 \pm 1.65(52.19)$ \\
\hline & Cool and dry & $0.69 \pm 0.02(0.64)$ & $1.42 \pm 0.03(1.32)$ & $55.87 \pm 3.65(51.81)$ & $0.74 \pm 0.06(0.69)$ & $2.39 \pm 0.12(2.21)$ & $46.72 \pm 0.01$ \\
\hline & Hot and dry & $1.33 \pm 0.01(4.49)$ & $1.87 \pm 0.00(6.34)$ & $3.46 \pm 0.00(11.71)$ & $3.63 \pm 0.01(12.26)$ & $5.57 \pm 0.01(18.84)$ & $13.71 \pm 0.01(46.37)$ \\
\hline & Warm and wet & $0.39 \pm 0.03(1.52)$ & $1.72 \pm 0.04(6.76)$ & $2.47 \pm 0.01(9.71)$ & $1.84 \pm 0.00(7.22)$ & $5.33 \pm 0.01(20.95)$ & $13.70 \pm 0.03(53.85)$ \\
\hline & Warm and dry & $1.53 \pm 0.11(5.35)$ & $1.76 \pm 0.10(6.16)$ & $2.58 \pm 0.06(9.01)$ & $1.81 \pm 0.04(6.33)$ & $5.71 \pm 0.04(19.96)$ & $15.20 \pm 0.50(53.18)$ \\
\hline \multirow{4}{*}{ Control } & Cool and dry & $0.02 \pm 0.01(0.04)$ & $0.03 \pm 0.01(0.06)$ & $0.01 \pm 0.01(0.03)$ & $0.32 \pm 0.07(0.67)$ & $0.09 \pm 0.10(0.20)$ & $47.00 \pm 0.01(99.00)$ \\
\hline & Hot and dry & $0.02 \pm 0.01(0.14)$ & $0.03 \pm 0.01(0.19)$ & $0.01 \pm 0.01(0.10)$ & $0.02 \pm 0.01(0.17)$ & $0.03 \pm 0.01(0.24)$ & $13.71 \pm 0.01(99.16)$ \\
\hline & Warm and wet & $0.02 \pm 0.01(0.14)$ & $0.03 \pm 0.01(0.19)$ & $0.01 \pm 0.01(0.10)$ & $0.02 \pm 0.01(0.17)$ & $0.03 \pm 0.01(0.24)$ & $13.71 \pm 0.01$ (99.16) \\
\hline & Warm and dry & & & & & na & na \\
\hline
\end{tabular}

Value in parenthesis () is the percentage fraction.

Table 19. Chemical fractionation of $\mathrm{Cu}(\mathrm{mg} / \mathrm{kg})$ in soil samples of irrigation farmlands along Kawo dam.

\begin{tabular}{|c|c|c|c|c|c|c|c|}
\hline Site & Season & Water Soluble & Exchangeable & Organic Bound & Carbonate Bound & Fe-MnO & Residual \\
\hline \multirow{4}{*}{1} & Cool and dry & $0.72 \pm 0.01(1.50)$ & $2.90 \pm 0.02(6.02)$ & $1.44 \pm 0.02(2.99)$ & $1.23 \pm 0.06(2.56)$ & $1.67 \pm 0.01(3.48)$ & $40.19 \pm 0.01(83.46)$ \\
\hline & Hot and dry & $0.28 \pm 0.01(11.320$ & $0.06 \mathrm{v} 0.00(2.52)$ & $0.32 \pm 0.00(12.92)$ & $0.96 \pm 0.01$ (38.38) & $0.38 \pm 0.00(14.94)$ & $0.50 \pm 0.00$ (19.92) \\
\hline & Warm and wet & $0.27 \pm 0.00(4.61)$ & $0.37 \pm 0.00(6.39)$ & $3.83 \pm 0.01(65.93)$ & $0.74 \pm 0.00(12.78)$ & $0.38 \pm 0.00(6.45)$ & $0.22 \pm 0.00$ \\
\hline & Warm and dry & $0.86 \pm 0.05(12.42)$ & $0.57 \pm 0.05(8.23)$ & $1.69 \pm 0.11(24.35)$ & $1.47 \pm 0.05$ (21.27) & $1.60 \pm 0.04(23.10)$ & $0.74 \pm 0.09$ (10.64) \\
\hline \multirow{4}{*}{2} & Cool and dry & $0.72 \pm 0.02(1.48)$ & $2.92 \pm 0.06(6.01)$ & $1.36 \pm 0.06(2.80)$ & $1.14 \pm 0.06(2.34)$ & $1.62 \pm 0.06(3.34)$ & $40.87 \pm 0.50(84.04)$ \\
\hline & Hot and dry & $0.26 \pm 0.05(10.82)$ & $0.07 \pm 0.00(2.94)$ & $0.32 \pm 0.00(13.27)$ & $0.95 \pm 0.01$ (39.05) & $0.37 \pm 0.00(15.21)$ & $0.45 \pm 0.01(18.70)$ \\
\hline & Warm and wet & $0.27 \pm 0.00(4.67)$ & $0.37 \pm 0.00(6.42)$ & $3.78 \pm 0.01(65.82)$ & $0.74 \pm 0.00(12.87)$ & $0.37 \pm 0.00(6.42)$ & $0.22 \pm 0.00(3.80)$ \\
\hline & Warm and dry & $0.86 \pm 0.06(12.54)$ & $0.62 \pm 0.03(9.04)$ & $1.64 \pm 0.07$ (23.78) & $1.48 \pm 0.03(21.51)$ & $1.61 \pm 0.03(23.45)$ & $0.67 \pm 0.01$ (9.69) \\
\hline \multirow{4}{*}{3} & Cool and dry & $0.74 \pm 0.02(1.50)$ & $2.89 \pm 0.01(5.88)$ & $1.48 \pm 0.17(3.01)$ & $1.10 \pm 0.12(2.24)$ & $1.60 \pm 0.03(3.26)$ & $41.33 \pm 0.83(84.11)$ \\
\hline & Hot and dry & $0.16 \pm 0.01(7.06)$ & $0.06 \pm 0.00(2.47)$ & $0.31 \pm 0.00(14.02)$ & $0.86 \pm 0.01(38.48)$ & $0.37 \pm 0.00(16.58)$ & $0.48 \pm 0.03$ (21.39) \\
\hline & Warm and wet & $0.27 \pm 0.00(4.66)$ & $0.37 \pm 0.00(6.44)$ & $3.76 \pm 0.01(65.72)$ & $0.74 \pm 0.00(12.87)$ & $0.37 \pm 0.00(6.51)$ & $0.22 \pm 0.00(3.80)$ \\
\hline & Warm and dry & $1.08 \pm 0.03$ (14.69) & $0.72 \pm 0.03(9.82)$ & $1.68 \pm 0.06(22.80)$ & $1.45 \pm 0.02(19.76)$ & $1.60 \pm 0.04(21.80)$ & $0.82 \pm 0.21(11.13)$ \\
\hline \multirow{4}{*}{4} & Cool and dry & $0.70 \pm 0.02(1.46)$ & $2.83 \pm 0.05$ (5.89) & $1.38 \pm 0.05(2.87)$ & $1.13 \pm 0.15(2.36)$ & $1.61 \pm 0.05(3.36)$ & $40.36 \pm 0.30(84.06)$ \\
\hline & Hot and dry & $0.26 \pm 0.05(11.48)$ & $0.05 \pm 0.00(2.10)$ & $0.31 \pm 0.00(14.03)$ & $0.77 \pm 0.01$ (34.62) & $0.37 \pm 0.00(16.64)$ & $0.47 \pm 0.03(21.13)$ \\
\hline & Warm and wet & $0.26 \pm 0.00(4.57)$ & $0.37 \pm 0.00(6.38)$ & $3.80 \pm 0.02(66.03)$ & $0.74 \pm 0.00(12.80)$ & $0.37 \pm 0.00(6.44)$ & $0.22 \pm 0.01(3.78)$ \\
\hline & Warm and dry & $0.99 \pm 0.07$ (13.81) & $0.63 \pm 0.04(8.80)$ & $1.66 \pm 0.08$ (23.05) & $1.41 \pm 0.05$ (19.53) & $1.81 \pm 0.20$ (25.09) & $0.70 \pm 0.04(9.72)$ \\
\hline \multirow{4}{*}{5} & Cool and dry & $0.70 \pm 0.02(1.45)$ & $2.80 \pm 0.07(5.76)$ & $1.42 \pm 0.12(2.91)$ & $1.10 \pm 0.11(2.26)$ & $1.67 \pm 0.03(3.43)$ & $40.96 \pm 0.67(84.20)$ \\
\hline & Hot and dry & $0.22 \pm 0.01(9.53)$ & $0.04 \pm 0.00(1.92)$ & $0.32 \pm 0.01(13.87)$ & $0.84 \pm 0.00(36.75)$ & $0.37 \pm 0.00(16.14)$ & $0.50 \pm 0.03(21.79)$ \\
\hline & Warm and wet & $0.24 \pm 0.04(4.20)$ & $0.37 \pm 0.00(6.47)$ & $3.76 \pm 0.02(66.09)$ & $0.74 \pm 0.00(12.91)$ & $0.37 \pm 0.00(6.50)$ & $0.22 \pm 0.00$ \\
\hline & Warm and dry & $1.02 \pm 0.08$ (13.81) & $0.58 \pm 0.05(7.90)$ & $1.62 \pm 0.09(21.90)$ & $1.52 \pm 0.04(20.55)$ & $1.84 \pm 0.18(24.83)$ & $0.81 \pm 0.17(11.01)$ \\
\hline \multirow{4}{*}{ Control } & Cool and dry & $0.02 \pm 0.01(0.05)$ & $0.95 \pm 0.06(2.16)$ & $0.70 \pm 0.03(1.58)$ & $0.79 \pm 0.35(1.80)$ & $0.91 \pm 0.60(2.07)$ & $40.68 \pm 0.58(92.35)$ \\
\hline & Hot and dry & $0.02 \pm 0.01(1.21)$ & $0.01 \pm 0.01(0.84)$ & $0.06 \pm 0.01(3.42)$ & $0.51 \pm 0.05$ (30.97) & $0.54 \pm 0.06(32.38)$ & $0.52 \pm 0.01(31.17)$ \\
\hline & Warm and wet & $0.02 \pm 0.01(1.47)$ & $0.01 \pm 0.01(1.03)$ & $0.06 \pm 0.01(4.15)$ & $0.51 \pm 0.05$ (37.61) & $0.54 \pm 0.06$ (39.32) & $0.22 \pm 0.01(16.43)$ \\
\hline & Warm and dry & na & na & na & na & na & na \\
\hline
\end{tabular}

Value in parenthesis () is the percentage fraction. 
Table 20. Chemical fractionation of Fe (mg/kg) in soil samples of irrigation farmlands along Kawo dam.

\begin{tabular}{|c|c|c|c|c|c|c|c|}
\hline Site & Season & Water Soluble & Exchangeable & Organic Bound & Carbonate Bound & Fe-MnO & Residual \\
\hline \multirow{4}{*}{1} & Cool and dry & $5.54 \pm 0.10(0.79)$ & $25.13 \pm 0.23(3.58)$ & $16.85 \pm 0.01(2.40)$ & $14.05 \pm 0.01(2.00)$ & $8.42 \pm 0.02(1.20)$ & $631.73 \pm 0.12(90.03)$ \\
\hline & Hot and dry & $13.93 \pm 0.01(.044)$ & $6.17 \pm 0.01(0.20)$ & $92.98 \pm 0.01(2.94)$ & $23.40 \pm 0.10(0.74)$ & $1030.24 \pm 0.01(32.58)$ & $1995.47 \pm 0.06(63.10$ \\
\hline & Warm and wet & $10.42 \pm 0.02(0.25)$ & $9.42 \pm 0.01(0.23)$ & $45.80 \pm 0.03(1.12)$ & $24.36 \pm 0.04(0.59)$ & $836.01 \pm 1.21$ (20.39) & $3173.17 \pm 0.15(77.42)$ \\
\hline & Warm and dry & $12.19 \pm 0.35(0.38)$ & $9.34 \pm 0.31(0.29)$ & $46.89 \pm 1.48(1.46)$ & $23.26 \pm 0.43(0.73)$ & $978.28 \pm 1.53(30.54)$ & $2132.94 \pm 1.38$ (66.59) \\
\hline \multirow{4}{*}{2} & Cool and dry & $5.55 \pm 0.03(0.79)$ & $25.06 \pm 0.33(3.58)$ & $16.47 \pm 0.43(2.35)$ & $13.96 \pm 0.07$ (1.99) & $8.35 \pm 0.34$ (1.19) & $630.55 \pm 0.59$ (90.09) \\
\hline & Hot and dry & $12.81 \pm 0.06(0.41)$ & $6.04 \pm 0.00(0.19)$ & $92.91 \pm 0.06(2.94)$ & $23.19 \pm 0.02(0.73)$ & $1030.20 \pm 0.03(32.60)$ & $1995.27 \pm 0.06(63.13)$ \\
\hline & Warm and wet & $10.14 \pm 0.34(0.25)$ & $9.40 \pm 0.02(0.23)$ & $45.70 \pm 0.06(1.11)$ & $24.41 \pm 0.04(0.60)$ & $836.70 \pm 0.56(20.41)$ & $3173.40 \pm 0.10(77.40)$ \\
\hline & Warm and dry & $12.11 \pm 0.38(0.38)$ & $9.74 \pm 0.10(0.31)$ & $45.81 \pm 1.67(1.45)$ & $22.93 \pm 0.52(0.73)$ & $940.74 \pm 5.83(29.77)$ & $2129.18 \pm 9.03(67.37)$ \\
\hline \multirow{4}{*}{3} & Cool and dry & $5.63 \pm 0.02(0.80)$ & $25.18 \pm 0.17$ (3.59) & $16.01 \pm 1.08(2.29)$ & $14.05 \pm 0.06(2.00)$ & $8.36 \pm 0.07$ (1.19) & $631.37 \pm 0.43(90.12)$ \\
\hline & Hot and dry & $11.95 \pm 0.01(0.38)$ & $5.75 \pm 0.01(0.18)$ & $92.80 \pm 0.05(2.94)$ & $23.16 \pm 0.01(0.73)$ & $1030.17 \pm 0.01(32.61)$ & $1995.03 \pm 0.22(63.16)$ \\
\hline & Warm and wet & $10.40 \pm 0.04(0.27)$ & $9.37 \pm 0.02(0.25)$ & $44.84 \pm 0.06(1.17)$ & $24.29 \pm 0.30(0.64)$ & $560.37 \pm 478.01(14.66)$ & $3172.30 \pm 3.38(83.01)$ \\
\hline & Warm and dry & $11.77 \pm 0.05(0.46)$ & $9.37 \pm 0.43(0.37)$ & $47.25 \pm 0.50(1.86)$ & $23.61 \pm 0.11(0.93)$ & $921.13 \pm 1.33(36.21)$ & $1530.73 \pm 32.29(60.17)$ \\
\hline \multirow{4}{*}{4} & Cool and dry & $5.64 \pm 0.02(0.80)$ & $25.11 \pm 0.58(3.58)$ & $16.28 \pm 0.41(2.32)$ & $13.96 \pm 0.07$ (1.99) & $8.43 \pm 0.03(1.20)$ & $631.53 \pm 1.36(90.10)$ \\
\hline & Hot and dry & $10.60 \pm 0.02(0.34)$ & $5.65 \pm 0.01(0.18)$ & $92.77 \pm 0.01(2.94)$ & $22.86 \pm 0.01(0.72)$ & $1030.22 \pm 0.01(32.63)$ & $1994.68 \pm 0.08$ (63.19) \\
\hline & Warm and wet & $\begin{array}{c}3452.05 \pm \\
61.68(45.78)\end{array}$ & $9.34 \pm 0.01(0.12)$ & $44.83 \pm 0.06(0.59)$ & $24.00 \pm 0.29(0.32)$ & $836.63 \pm 0.58(11.10)$ & $3173.17 \pm 0.59(42.08)$ \\
\hline & Warm and dry & $12.18 \pm 0.31(0.40)$ & $8.96 \pm 0.43(0.29)$ & $47.52 \pm 0.78(1.54)$ & $22.70 \pm 0.85(0.74)$ & $884.79 \pm 8.90(28.76)$ & $2100.62 \pm 8.00(68.27)$ \\
\hline \multirow{4}{*}{5} & Cool and dry & $4.90 \pm 0.59(0.70)$ & $25.11 \pm 0.21$ (3.59) & $16.42 \pm 0.59(2.35)$ & $13.98 \pm 0.08(2.00)$ & $8.48 \pm 0.06(1.21)$ & $630.86 \pm 0.50(90.16)$ \\
\hline & Hot and dry & $12.58 \pm 0.06(0.40)$ & $5.34 \pm 0.00(0.17)$ & $92.76 \pm 0.01(2.94)$ & $22.77 \pm 0.02(0.72)$ & $1029.76 \pm 0.01(32.60)$ & $1995.47 \pm 0.12(63.17)$ \\
\hline & Warm and wet & $10.36 \pm 0.05(0.25)$ & $9.32 \pm 0.01(0.23)$ & $44.36 \pm 0.33(1.08)$ & $24.01 \pm 0.34(0.59)$ & $834.96 \pm 1.46(20.39)$ & $3171.57 \pm 3.72(77.46)$ \\
\hline & Warm and dry & $12.13 \pm 0.31(0.39)$ & $9.35 \pm 0.07(0.30)$ & $46.63 \pm 0.79(1.50)$ & $23.89 \pm 0.29(0.77)$ & $976.64 \pm 10.05(31.33)$ & $2049.09 \pm 7.79(65.72)$ \\
\hline \multirow{4}{*}{ Control } & Cool and dry & $4.21 \pm 0.21(0.65)$ & $2.51 \pm 0.21(0.39)$ & $2.36 \pm 0.18(0.36)$ & $6.28 \pm 6.68(0.97)$ & $4.54 \pm 3.35(0.70)$ & $630.33 \pm 0.58(96.94)$ \\
\hline & Hot and dry & $4.32 \pm 0.11(0.22)$ & $2.22 \pm 0.01(0.11)$ & $2.36 \pm 0.18(0.12)$ & $2.41 \pm 0.11(0.12)$ & $2.53 \pm 0.13(0.13)$ & $1994.87 \pm 0.23(99.31)$ \\
\hline & Warm and wet & $4.32 \pm 0.11(0.14)$ & $2.22 \pm 0.01(0.07)$ & $2.36 \pm 0.18(0.07)$ & $2.41 \pm 0.11(0.08)$ & $2.53 \pm 0.13(0.08)$ & $3172.17 \pm 0.29(9.57)$ \\
\hline & Warm and dry & na & na & na & na & na & na \\
\hline
\end{tabular}

Value in parenthesis () is the percentage fraction.

Table 21. Chemical fractionation of $\mathrm{Mn}(\mathrm{mg} / \mathrm{kg})$ in soil samples of irrigation farmlands along Kawo dam.

\begin{tabular}{cccccccc}
\hline Site & Season & Water Soluble & Exchangeable & Organic Bound & Carbonate Bound & Fe-MnO & Residual \\
\hline & Cool and dry & $0.16 \pm 0.00(2.03)$ & $0.20 \pm 0.00(2.66)$ & $0.56 \pm 0.00(7.34)$ & $0.10 \pm 0.00(1.33)$ & $0.25 \pm 0.00(93.32)$ & $6.37 \pm 0.01(83.32)$ \\
& Hot and dry & $0.42 \pm 0.00(1.61)$ & $12.74 \pm 0.04(48.49)$ & $0.04 \pm 0.00(0.14)$ & $0.23 \pm 0.00(0.89)$ & $1.74 \pm 0.00(6.61)$ & $11.10 \pm 0.10(42.26)$ \\
& Warm and wet & $0.57 \pm 0.00(1.94)$ & $13.28 \pm 0.06(44.93)$ & $0.06 \pm 0.00(0.21)$ & $0.43 \pm 0.00(1.46)$ & $1.80 \pm 0.03(6.08)$ & $13.42 \pm 0.02(45.38)$ \\
& Warm and dry & $1.44 \pm 0.12(4.95)$ & $13.52 \pm 0.10(46.58)$ & $0.11 \pm 0.04(0.38)$ & $0.39 \pm 0.03(1.33)$ & $1.64 \pm 0.05(5.65)$ & $11.93 \pm 0.55(41.11)$ \\
& Cool and dry & $0.15 \pm 0.00(2.02)$ & $0.20 \pm 0.00(2.66)$ & $0.52 \pm 0.04(6.85)$ & $0.11 \pm 0.00(1.41)$ & $0.25 \pm 0.01(3.28)$ & $6.36 \pm 0.04(83.79)$ \\
& Hot and dry & $0.44 \pm 0.02(1.77)$ & $11.75 \pm 0.01(47.79)$ & $0.04 \pm 0.00(0.15)$ & $0.22 \pm 0.01(0.91)$ & $1.73 \pm 0.00(7.05)$ & $10.41 \pm 0.60(42.33)$ \\
2 & Warm and wet & $0.56 \pm 0.02(1.90)$ & $13.32 \pm 0.10(45.07)$ & $0.06 \pm 0.000(0.21)$ & $0.40 \pm 0.01(1.35)$ & $1.79 \pm 0.02(6.05)$ & $13.42 \pm 0.01(45.42)$ \\
& Warm and dry & $1.34 \pm 0.10(4.64)$ & $13.05 \pm 0.44(45.11)$ & $0.12 \pm 0.04(0.40)$ & $0.39 \pm 0.03(1.35)$ & $1.72 \pm 0.04(5.94)$ & $12.32 \pm 0.50(42.56)$ \\
& Cool and dry & $0.16 \pm 0 . .00(2.05)$ & $0.20 \pm 0.00(2.68)$ & $0.51 \pm 0.05(6.78)$ & $0.10 \pm 0.00(1.31)$ & $0.25 \pm 0.00(3.28)$ & $6.36 \pm 0.04(83.91)$ \\
& Hot and dry & $0.49 \pm 0.05(2.02)$ & $11.65 \pm 0.01(47.50)$ & $0.03 \pm 0.00(0.13)$ & $0.21 \pm 0.00(0.86)$ & $1.73 \pm 0.00(7.06)$ & $10.41 \pm 0.60(42.43)$ \\
3 & Warm and wet & $0.59 \pm 0.03(2.00)$ & $13.14 \pm 0.14(44.69)$ & $0.06 \pm 0.00(0.21)$ & $0.42 \pm 0.01(1.42)$ & $1.81 \pm 0.01(6.14)$ & $13.39 \pm 0.03(45.53)$ \\
& Warm and dry & $1.23 \pm 0.15(4.36)$ & $12.82 \pm 0.46(45.39)$ & $0.10 \pm 0.00(0.34)$ & $0.39 \pm 0.02(1.37)$ & $1.65 \pm 0.10(5.84)$ & $12.06 \pm 0.51(42.71)$ \\
\hline
\end{tabular}




\begin{tabular}{|c|c|c|c|c|c|c|c|}
\hline \multicolumn{8}{|c|}{ Continued } \\
\hline \multirow{4}{*}{4} & Cool and dry & $0.15 \pm 0.00(2.01)$ & $0.20 \pm 0.00(2.69)$ & $0.50 \pm 0.01(6.66)$ & $0.10 \pm 0.00(1.36)$ & $0.25 \pm 0.00(3.37)$ & $6.30 \pm 0.04(83 . .91)$ \\
\hline & Hot and dry & $0.48 \pm 0.04(1.93)$ & $11.52 \pm 0.04(46.62)$ & $0.03 \pm 0.00(0.11)$ & $0.20 \pm 0.00(0.80)$ & $1.70 \pm 0.03(6.88)$ & $10.78 \pm 0.64(43.66)$ \\
\hline & Warm and wet & $0.53 \pm 0.04(1.83)$ & $13.00 \pm 0.37(44.53)$ & $0.06 \pm 0.00(0.21)$ & $0.43 \pm 0.00(1.46)$ & $1.77 \pm 0.02(6.06)$ & $13.40 \pm 0.03(45.91$ \\
\hline & Warm and dry & $1.14 \pm 0.08$ (3.97) & $13.22 \pm 0.43(46.08)$ & $0.12 \pm 0.02(0.40)$ & $0.41 \pm 0.03(1.42)$ & $1.72 \pm 0.04(6.01)$ & $12.08 \pm 0.48(42.11)$ \\
\hline \multirow{4}{*}{5} & Cool and dry & $0.15 \pm 0.00(1.99)$ & $0.20 \pm 0.00(2.64)$ & $0.54 \pm 0.04(7.06)$ & $0.10 \pm 0.01(1.37)$ & $0.25 \pm 0.00(3.34)$ & $6.35 \pm 0.05$ (83.59) \\
\hline & Hot and dry & $0.46 \pm 0.05(1.93)$ & $11.40 \pm 0.03(47.85)$ & $0.03 \pm 0.00(0.14)$ & $0.20 \pm 0.00(0.82)$ & $1.68 \pm 0.01(7.06)$ & $10.05 \pm 0.01(42.20)$ \\
\hline & Warm and wet & $0.54 \pm 0.05(1.84)$ & $13.20 \pm 0.02(44.95)$ & $0.05 \pm 0.00(0.19)$ & $0.42 \pm 0.02(1.42)$ & $1.76 \pm 0.06(5.98)$ & $13.40 \pm 0.03(45.63)$ \\
\hline & Warm and dry & $1.28 \pm 0.19$ & $13.14 \pm 0.33(45.11)$ & $0.10 \pm 0.02(0.33)$ & $0.38 \pm 0.02(1.29)$ & $1.84 \pm 0.16(6.33)$ & $12.40 \pm 0.75(42.55)$ \\
\hline \multirow{4}{*}{ Control } & Cool and dry & $0.05 \pm 0.00(0.78)$ & $0.02 \pm 0.02(0.26)$ & $0.07 \pm 0.01(1.07)$ & $0.07 \pm 0.03(1.05)$ & $0.12 \pm 0.11(1.78)$ & $6.53 \pm 0.06(95.05)$ \\
\hline & Hot and dry & $0.05 \pm 0.00(0.48)$ & $1.18 \pm 0.06(10.41)$ & $0.00 \pm 0.00(0.03)$ & $0.06 \pm 0.00(0.50)$ & $0.06 \pm 0.00(0.50)$ & $10.02 \pm 0.03(88.08)$ \\
\hline & Warm and wet & $0.05 \pm 0.00(0.37)$ & $1.18 \pm 0.06(8.03)$ & $0.00 \pm 0.00(0.02)$ & $0.06 \pm 0.00(0.39)$ & $0.06 \pm 0.00(0.38)$ & $13.39 \pm 0.02(90.81)$ \\
\hline & Warm and dry & na & na & na & na & na & na \\
\hline
\end{tabular}

Value in parenthesis () is the percentage fraction.

Table 22. Chemical fractionation of $\mathrm{Ni}(\mathrm{mg} / \mathrm{kg})$ in soil samples of irrigation farmlands along Kawo dam.

\begin{tabular}{|c|c|c|c|c|c|c|c|}
\hline Site & Season & Water Soluble & Exchangeable & Organic Bound & Carbonate Bound & Fe-MnO & Residual \\
\hline \multirow{4}{*}{1} & Cool and dry & $2.53 \pm 0.02(1.84)$ & $7.34 \pm 0.02(5.34)$ & $6.21 \pm 0.02(4.52)$ & $3.23 \pm 0.02(2.35)$ & $2.4 \pm 0.04(1.99)$ & $115.47 \pm 0.42(83.87)$ \\
\hline & Hot and dry & $0.66 \pm 0.01(4.27)$ & $1.91 \pm 0.00(12.38)$ & $1.65 \pm 0.01(10.66)$ & $0.76 \pm 0.01(4.90)$ & $5.33 \pm 0.06(34.51)$ & $5.15 \pm 0.01(33.29)$ \\
\hline & Warm and wet & $0.54 \pm 0.00$ & $2.01 \pm 0.00(11.48)$ & $1.76 \pm 0.00(10.05)$ & $0.94 \pm 0.00$ & $7.64 \pm 0.01$ & $4 . .65 \pm 0.00(26.51)$ \\
\hline & Warm and dry & $6.52 \pm 0.58(61.38)$ & $1.31 \pm 0.06(3.02)$ & $1.82 \pm 0.07(4.20)$ & $1.47 \pm 0.05$ & $6.71 \pm 0.11(15.54)$ & $5.38 \pm 0.42(12.45)$ \\
\hline \multirow{4}{*}{2} & Cool and dry & $2.52 \pm 0.01(1.83)$ & $7.35 \pm 0.02(5.34)$ & $6.06 \pm 0.21(4.40)$ & $3.25 \pm 0.06(2.36)$ & $2.71 \pm 0.04$ (1.97) & $115.70 \pm 0.89$ (84.09) \\
\hline & Hot and dry & $0.62 \pm 0.04$ & $1.85 \pm 0.00(12.33)$ & $1.57 \pm 0.02(10.42)$ & $0.68 \pm 0.01(4.50)$ & $5.19 \pm 0.01(34.54)$ & $5.13 \pm 0.01(34.10)$ \\
\hline & Warm and wet & $0.45 \pm 0.00$ & $2.02 \pm 0.01(11.53)$ & $1.76 \pm 0.00(10.05)$ & $0.94 \pm 0.00$ & $7.61 \pm 0.04(43.52)$ & $4.63 \pm 0.04(26 . .48)$ \\
\hline & Warm and dry & $0.85 \pm 0.03(4.90)$ & $1.37 \pm 0.07(7.90)$ & $1.83 \pm 0.08(10.57)$ & $1.49 \pm 0.03(8.57)$ & $6.44 \pm 0.48(37.10)$ & $5.37 \pm 0.43(30.96)$ \\
\hline \multirow{4}{*}{3} & Cool and dry & $2.53 \pm 0.01(1.84)$ & $7.34 \pm 0.02(5.34)$ & $6.25 \pm 0.33(4.54)$ & $3.17 \pm 0.17(2.30)$ & $2.73 \pm 0.03(1.98)$ & $115.43 \pm 0.49$ \\
\hline & Hot and dry & $0.58 \pm 0.05$ & $1.79 \pm 0.00(12.22)$ & $1.55 \pm 0.01(10.59)$ & $0.66 \pm 0.01(4.49)$ & $5.17 \pm 0.01$ & $4.87 \pm 0.21(33.36)$ \\
\hline & Warm and wet & $0.53 \pm 0.01$ & $2.01 \pm 0.00(11.51)$ & $1.76 \pm 0.00(10.08)$ & $0.93 \pm 0.00$ & $7.63 \pm 0.01$ & $4.62 \pm 0.04(26.40)$ \\
\hline & Warm and dry & $0.98 \pm 0.07(5.76)$ & $1.43 \pm 0.10(8.43)$ & $1.81 \pm 0.06(10.67)$ & $1.49 \pm 0.04(8.79)$ & $6.14 \pm 0.38$ & $5.11 \pm 0.31(30.12)$ \\
\hline \multirow{4}{*}{$A$} & Cool and dry & $2.54 \pm 0.02(1.86)$ & $7.11 \pm 0.22(5.21)$ & $6.03 \pm 0.16(4.42)$ & $3.18 \pm 0.16(2.33)$ & $2.72 \pm 0.02(2.00)$ & $114.81 \pm 0.81(84.18)$ \\
\hline & Hot and dry & $3.70 \pm 0.15$ (21.39) & $1.76 \pm 0.00(10.15)$ & $1.49 \pm 0.04(8.60)$ & $0.74 \pm 0.01(4.26)$ & $4.87 \pm 0.01(28.18)$ & $4.74 \pm 0.01(27.43)$ \\
\hline & Warm and wet & $0.52 \pm 0.02(2.98)$ & $2.01 \pm 0.00(11.51)$ & $1.76 \pm 0.00(10.07)$ & $0.91 \pm 0.02$ (5.19) & $7.63 \pm 0.02(43.65)$ & $4.65 \pm 0.01$ (26.59) \\
\hline & Warm and dry & $0.98 \pm 0.07(5.76)$ & $1.43 \pm 0.10(8.43)$ & $1.81 \pm 0.06(10.67)$ & $1.49 \pm 0.04$ (8.79) & $6.14 \pm 0.38(36.23)$ & $5.11 \pm 0.31(30.12)$ \\
\hline & Cool and dry & $2.52 \pm 0.05(1.84)$ & $7.36 \pm 0.05(5.38)$ & $6.11 \pm 0.22(4.47)$ & $3.11 \pm 0.11(2.27)$ & $2.65 \pm 0.16(1.94)$ & $115.08 \pm 0.33(84.10)$ \\
\hline & Hot and dry & $0.63 \pm 0.02(4.23)$ & $1.78 \pm 0.00(11.89)$ & $1.46 \pm 0.02(9.80)$ & $0.72 \pm 0.01(4.80)$ & $5.22 \pm 0.01(34.97)$ & $5.13 \pm 0.01(34.32)$ \\
\hline & Warm and wet & $0.53 \pm 0.01(3.09)$ & $2.02 \pm 0.01(11.84)$ & $1.76 \pm 0.00(10.30)$ & $0.93 \pm 0.00(5.48)$ & $7.17 \pm 0.33(42.08)$ & $4.64 \pm 0.02(27.21)$ \\
\hline & Warm and dry & $0.88 \pm 0.07(4.97)$ & $1.36 \pm 0.08$ (7.69) & $1.77 \pm 0.03(10.05)$ & $1.48 \pm 0.05$ (8.39) & $6.49 \pm 0.46(36.81)$ & $5.66 \pm 0.11(32.08)$ \\
\hline \multirow{4}{*}{ Control } & Cool and dry & $1.31 \pm 0.05(1.06)$ & $1.85 \pm 0.08$ (1.49) & $1.49 \pm 0.05(1.20)$ & $1.84 \pm 1.19$ (1.48) & $1.46 \pm 0.90(1.18)$ & $116.00 \pm 0.00$ \\
\hline & Hot and dry & $1.31 \pm 0.05(12 . .85)$ & $0.34 \pm 0.01$ (3.29) & $1.44 \pm 0.05(14.16)$ & $1.17 \pm 0.06(11.51)$ & $0.82 \pm 0.09$ & $5.11 \pm 0.01(50.10)$ \\
\hline & Warm and wet & $1.31 \pm 0.05(13.49)$ & $0.34 \pm 0.01(3.46)$ & $1.42 \pm 0.02(1462)$ & $1.17 \pm 0.06(12.08)$ & $0.82 \pm 0.09(8.48)$ & $4.65 \pm 0.00(47.88)$ \\
\hline & Warm and dry & na & na & na & na & na & na \\
\hline
\end{tabular}

Value in parenthesis () is the percentage fraction. 
Table 23. Chemical fractionation of $\mathrm{Pb}(\mathrm{mg} / \mathrm{kg})$ in soil samples of irrigation farmlands along Kawo dam.

\begin{tabular}{|c|c|c|c|c|c|c|c|}
\hline Site & Season & Water Soluble & Exchangeable & Organic Bound & Carbonate Bound & Fe-MnO & Residual \\
\hline \multirow{4}{*}{1} & Cool and dry & $1.72 \pm 0.03$ (1.04) & $2.71 \pm 0.02(1.65)$ & $4.24 \pm 0.02(2.58)$ & $3.46 \pm 0.03(2.10)$ & $2.52 \pm 0.02(1.53)$ & $149.80 \pm 0.10(91.09)$ \\
\hline & Hot and dry & $1.73 \pm 0.06(13.49)$ & $2.86 \pm 0.00(22.28)$ & $0.69 \pm 0.00(5.35)$ & $2.13 \pm 0.01(16.56)$ & $1.19 \pm 0.00(32.59)$ & $1.25 \pm 0.00(9.73)$ \\
\hline & Warm and wet & $0.76 \pm 0.00(5.97)$ & $1.56 \pm 0.00(12.24)$ & $0.96 \pm 0.00(7.51)$ & $3.46 \pm 0.01(27.12)$ & $4.28 \pm 0.00(33.51)$ & $1.74 \pm 0.03(13.64)$ \\
\hline & Warm and dry & $1.24 \pm 0.08(9.44)$ & $1.81 \pm 0.04(13.80)$ & $0.80 \pm 0.05(6.09)$ & $3.50 \pm 0.07(26.76)$ & $4.40 \pm 0.12(33.62)$ & $1.35 \pm 0.02(10.29)$ \\
\hline \multirow{4}{*}{2} & Cool and dry & $1.73 \pm 0.01(1.06)$ & $2.70 \pm 0.02(1.66)$ & $4.07 \pm 0.16(2.50)$ & $3.40 \pm 0.15$ (2.09) & $2.49 \pm 0.05(1.53)$ & $148.50 \pm 0.53(91.17)$ \\
\hline & Hot and dry & $1.65 \pm 0.01(13.52)$ & $2.76 \pm 0.00(22.65)$ & $0.65 \pm 0.05(5.35)$ & $2.11 \pm 0.01(17.35)$ & $3.78 \pm 0.00$ (30.99) & $1.24 \pm 0.01(10.15)$ \\
\hline & Warm and wet & $0.76 \pm 0.00(5.99)$ & $1.55 \pm 0.00(12.21)$ & $0.96 \pm 0.00(7 . .52)$ & $3.41 \pm 0.03(26.85)$ & $4.27 \pm 0.00(33.63)$ & $1.75 \pm 0.00(13.80)$ \\
\hline & Warm and dry & $1.24 \pm 0.08(9.44)$ & $1.81 \pm 0.04(13.80)$ & $0.80 \pm 0.05(6.09)$ & $3.50 \pm 0.07(26.76)$ & $4.40 \pm 0.12(33.62)$ & $1.35 \pm 0.02(10.29)$ \\
\hline \multirow{4}{*}{3} & Cool and dry & $1.73 \pm 0.02(1.06)$ & $2.70 \pm 0.02(1.66)$ & $4.18 \pm 0.06(2.56)$ & $3.44 \pm 0.09(2.11)$ & $2.55 \pm 0.06(1.56)$ & $148.43 \pm 1.39(91.04)$ \\
\hline & Hot and dry & $1.73 \pm 0.06(13.89)$ & $2.64 \pm 0.00(21.17)$ & $0.59 \pm 0.02(4.70)$ & $2.08 \pm 0.01(16.70)$ & $4.20 \pm 0.04(33.68)$ & $1.23 \pm 0.01(9.86)$ \\
\hline & Warm and wet & $0.77 \pm 0.00(6.04)$ & $1.49 \pm 0.00(11.74)$ & $0.95 \pm 0.00(7.53)$ & $3.45 \pm 0.03(27.21)$ & $4.27 \pm 0.00(33.68)$ & $1.75 \pm 0.01(13.80)$ \\
\hline & Warm and dry & $1.13 \pm 0.07(8.77)$ & $1.85 \pm 0.07(14.27)$ & $0.83 \pm 0.03(6.39)$ & $3.49 \pm 0.04(26.95)$ & $4.26 \pm 0.23(32.90)$ & $1.39 \pm 0.03(10.72)$ \\
\hline \multirow{4}{*}{ 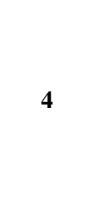 } & Cool and dry & $1.73 \pm 0.03(1.06)$ & $2.52 \pm 0.47(1.54)$ & $4.10 \pm 0.12(2.51)$ & $3.40 \pm 0.06(2.08)$ & $2.52 \pm 0.04(1.54)$ & $148.20 \pm 0.62(91.27)$ \\
\hline & Hot and dry & $1.55 \pm 0.01(13.45)$ & $2.56 \pm 0.01(20.76)$ & $0.65 \pm 0.00(5.30)$ & $2.07 \pm 0.01(16.75)$ & $4.18 \pm 0.00(33.85)$ & $1.22 \pm 0.01$ (9.89) \\
\hline & Warm and wet & $0.73 \pm 0.04(5.85)$ & $1.44 \pm 0.01(11.47)$ & $0.95 \pm 0.00(7.61)$ & $3.41 \pm 0.04(27.25)$ & $4.26 \pm 0.01(34.00)$ & $1.73 \pm 0.04(13.82)$ \\
\hline & Warm and dry & $1.14 \pm 0.16(8.78)$ & $1.69 \pm 0.08(13.04)$ & $0.82 \pm 0.09$ (6.29) & $3.40 \pm 0.07(26.21)$ & $4.54 \pm 0.19$ (34.99) & $1.39 \pm 0.10(10.68)$ \\
\hline & Cool and dry & $1.70 \pm 0.01(1.04)$ & $2.70 \pm 0.01(1.65)$ & $3.98 \pm 0.18(2.43)$ & $3.36 \pm 0.22(2.06)$ & $2.51 \pm 0.02(1.54)$ & $149.07 \pm 0.46(91.27)$ \\
\hline & Hot and dry & $1.64 \pm 0.01(13.46)$ & $2.52 \pm 0.03(20.70)$ & $0.54 \pm 0.04$ (4.43) & $2.09 \pm 0.02(17.21)$ & $4.15 \pm 0.00(34.16)$ & $1.22 \pm 0.01(10.03)$ \\
\hline & Warm and wet & $0.76 \pm 0.01(6.02)$ & $1.43 \pm 0.01(11.36)$ & $0.95 \pm 0.00(7.58)$ & $3.42 \pm 0.06(27.22)$ & $4.25 \pm 0.00(33.81)$ & $1.76 \pm 0.00(14.01)$ \\
\hline & Warm and dry & $1.12 \pm 0.08$ (8.17) & $1.82 \pm 0.04(13.25)$ & $0.99 \pm 0.11(7.18)$ & $3.22 \pm 0.31(23.46)$ & $5.14 \pm 0.23(37.39)$ & $1.45 \pm 0.14(10.55)$ \\
\hline \multirow{4}{*}{ Control } & Cool and dry & $0.08 \pm 0.06(0.05)$ & $0.21 \pm 0.10(0.14)$ & $0.13 \pm 0.06(0.09)$ & $1.17 \pm 1.97(0.77)$ & $1.00 \pm 1.30(0.66)$ & $150.00 \pm 0.00(98.30)$ \\
\hline & Hot and dry & $0.00 \pm 0.00(6.43)$ & $0.00 \pm 5.90(0.00)$ & $0.08 \pm 7.51(48.00)$ & $0.01 \pm 1.88(4.00)$ & $0.08 \pm 13.67(44.00)$ & $0.01 \pm 64.61(4.00)$ \\
\hline & Warm and wet & $0.12 \pm 0.01(5.12)$ & $0.11 \pm 0.01(4.71)$ & $0.13 \pm 0.06(5.40)$ & $0.04 \pm 0.01(1.66)$ & $0.25 \pm 0.06(10.38)$ & $1.75 \pm 0.00(72.73)$ \\
\hline & Warm and dry & na & na & na & na & na & na \\
\hline
\end{tabular}

Value in parenthesis () is the percentage fraction.

Table 24. Chemical fractionation of $\mathrm{Zn}(\mathrm{mg} / \mathrm{kg})$ in soil samples of irrigation farmlands along Kawo dam.

\begin{tabular}{|c|c|c|c|c|c|c|c|}
\hline Site & Season & Water Soluble & Exchangeable & Organic Bound & Carbonate Bound & Fe-MnO & Residual \\
\hline \multirow{4}{*}{1} & Cool and dry & $2.62 \pm 0.01(0.96)$ & $4.14 \pm 0.03(1.52)$ & $5.03 \pm 0.01(1.84)$ & $3.47 \pm 0.02(1.27)$ & $5.22 \pm 0.02(1.91)$ & $252.47 \pm 0.64(92.50)$ \\
\hline & Hot and dry & $3.13 \pm 0.00(1.37)$ & $7.56 \pm 0.00(3.32)$ & $101.50 \pm 0.03(44.61)$ & $12.05 \pm 0.01(5.30)$ & $78.04 \pm 0.00(34.30)$ & $25.24 \pm 0.01(11.10)$ \\
\hline & Warm and wet & $2.37 \pm 0.00(0.69)$ & $6.46 \pm 0.01(1.88)$ & $136.41 \pm 0.02(39.60)$ & $15.07 \pm 0.00(4.38)$ & $155.83 \pm 0.58(45.24)$ & $28.34 \pm 0.04(8.23)$ \\
\hline & Warm and dry & $\begin{array}{c}2.69 \pm 0.05 \\
(00.84)\end{array}$ & $5.74 \pm 0.12(1.79)$ & $125.75 \pm 1.01(39.12)$ & $13.63 \pm 0.06(4.24)$ & $147.27 \pm 0.35(45.82)$ & $26.33 \pm 0.50(8.19)$ \\
\hline \multirow{4}{*}{2} & Cool and dry & $2.63 \pm 0.01(0.97)$ & $4.13 \pm 0.01(1.52)$ & $5.00 \pm 0.12(1.84)$ & $3.48 \pm 0.03(1.28)$ & $5.35 \pm 0.16(1.97)$ & $251.23 \pm 0.31(92.43)$ \\
\hline & Hot and dry & $3.19 \pm 0.05(1.41)$ & $7.65 \pm 0.01$ (3.38) & $100.99 \pm 0.45(44.60)$ & $12.04 \pm 0.01(5.32)$ & $78.03 \pm 0.00(34.46)$ & $24.56 \pm 0.59(10.85)$ \\
\hline & Warm and wet & $2.38 \pm 0.03(0.69)$ & $6.45 \pm 0.01(1.88)$ & $135.66 \pm 0.59(39.48)$ & $14.96 \pm 0.19(4.35)$ & $155.82 \pm 0.58(45.35)$ & $28.34 \pm 0.02(8.25)$ \\
\hline & Warm and dry & $2.58 \pm 0.05(0.81)$ & $5.37 \pm 0.45(1.68)$ & $126.62 \pm 0.90(39.57)$ & $13.40 \pm 0.44(4.19)$ & $146.51 \pm 0.56(45.79)$ & $25.48 \pm 0.69(7.96)$ \\
\hline \multirow{4}{*}{3} & Cool and dry & $2.63 \pm 0.02(0.96)$ & $4.06 \pm 0.07$ (1.49) & $4.95 \pm 0.06(1.81)$ & $3.64 \pm 0.12(1.330$ & $5.36 \pm 0.07(1.96)$ & $252.67 \pm 0.38(92.440$ \\
\hline & Hot and dry & 3.15V0.05 (1.40) & $6.77 \pm 0.02(3.00)$ & $100.95 \pm 0.45(44.790$ & $11.94 \pm 0.15(5.30)$ & $78.03 \pm 0.00(34.62)$ & $24.57 \pm 0.57(10.90)$ \\
\hline & Warm and wet & $2.36 \pm 0.01(0.69)$ & $6.44 \mathrm{~V} 0.02$ (1.87) & $135.36 \pm 0.00(39.42)$ & $15.07 \pm 0.00$ (4.39) & $155.83 \pm 0.58(45.38)$ & $28.31 \pm 0.03(8.24)$ \\
\hline & Warm and dry & $2.46 \pm 0.11(0.77)$ & $5.18 \pm 0.45(1.62)$ & $125.72 \pm 0.84(39.30)$ & $13.46 \pm 0.42(4.21)$ & $147.17 \pm 0.63(46.01)$ & $25.89 \pm 0.55(8.09)$ \\
\hline
\end{tabular}




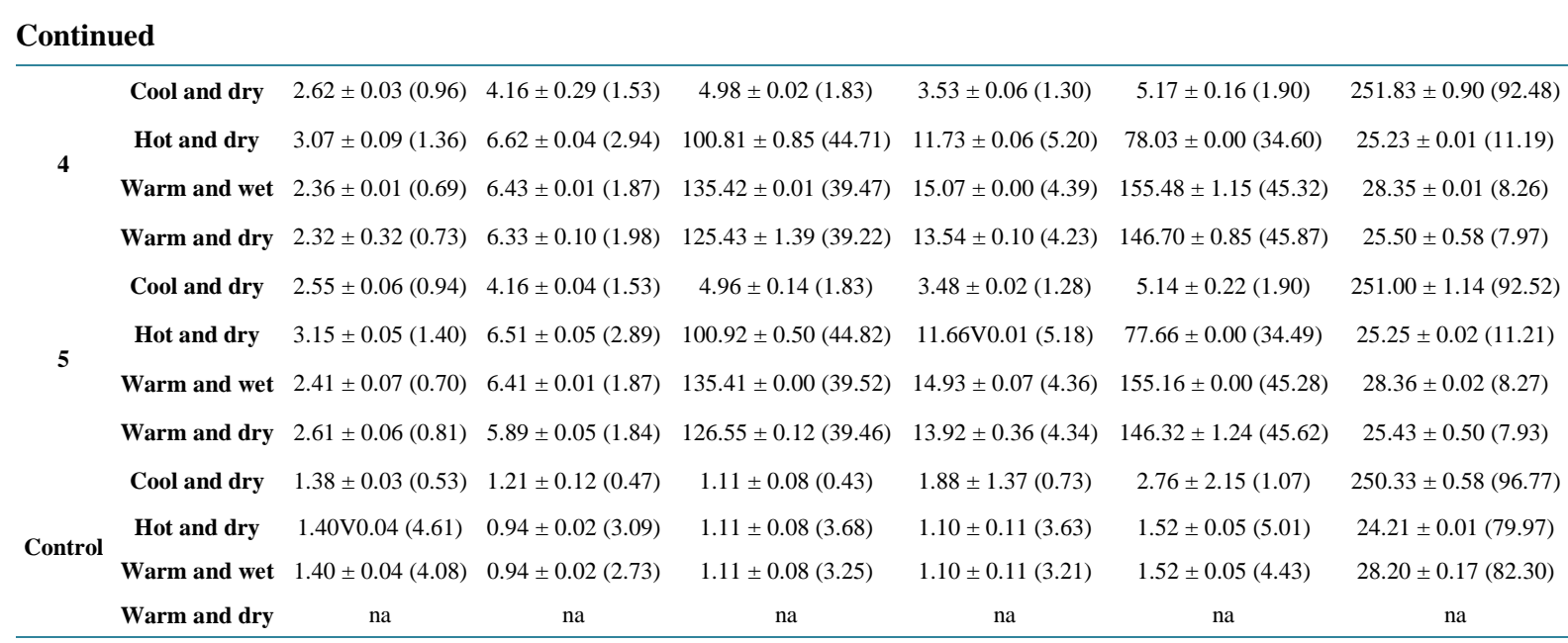

Value in parenthesis () is the percentage fraction.

est concentration $0.99 \mathrm{mg} / \mathrm{kg}$ is associated with the organic bound fraction for $\mathrm{Cd}$ in. This situation is however different from [13], where insignificant amount of $\mathrm{Cd}$ are associated with organic bound fraction, whereas in the other fractions $\mathrm{Cd}$ concentrations were below the limit of detection. Association of $\mathrm{Cd}$ to the organic bound fraction does not generally constitute an environmental risk. This is due to retention of this metal by ion-exchange proton displacement, and inner and out-spheres complex formation [32]. Consequently, considerable amount of $\mathrm{Cd}$ are retained in this fraction, which is less mobile, since it is considered to be associated with higher molecular weight stable and humic substance which release small amounts of metal gradually [33] (1999).

As shown in Table 18, Cr across the sites was dominant in the residual fraction across the seasons (13.68 $46.72 \mathrm{mg} / \mathrm{kg}$ ). Highest concentration in the residual of $\mathrm{Cr}$ was obtained in site $5 \mathrm{in}$ warm and dry season, then in the Fe-MnO fraction (2.38 - $5.80 \mathrm{mg} / \mathrm{kg})$. Highest concentration of $\mathrm{Cr}$ is associated with residual fraction. Small amount of $\mathrm{Cr}$ associated with water soluble fraction are noticed in all the sites. This is similar to [34] where no $\mathrm{Cr}$ was detected in the first three fractions. According to them, the leaching of $\mathrm{Cr}$ to the environment from these samples may not occur readily. $\mathrm{Cr}(\mathrm{VI})$ is a highly toxic metal that has been linked to cancer in humans following prolonged inhalation, and is toxic to plants at relatively low concentrations [35].

For $\mathrm{Cu}$ (Table 19), the residual (site 3) and organic bound (site 1) fractions exhibited the highest concentration of 41.33 and $3.83 \mathrm{mg} / \mathrm{kg}$ in cool and dry, and warm and wet season, respectively. Dominant level of $\mathrm{Cu}$ in the exchangeable phase at site 2 was observed, while in warm and dry season, the carbonate bound fraction dominated at site 5 .

Also, the predominant form of $\mathrm{Cu}$ available in the entire fractions is residual, exchangeable and carbonate bound fractions. The high \% of $\mathrm{Cu}$ in the residual fraction is due to stable nature of the compound and the fact that the metals are bonded firmly within a mineral lattice restricted the bioavailability of this metal [36] [37]. This coincides with the researches carried out on soils in China [38] [39].

Fe across the sites was also associated mostly with the residual phase followed by $\mathrm{Fe}-\mathrm{MnO}$ and organic bound fractions as shown in Table 20, the concentration ranged 630.33 - 3173.40, $8.35-1030.24,16.01-92.98 \mathrm{mg} / \mathrm{kg}$, respectively across the seasons. Highest concentration of $3173.40 \mathrm{mg} / \mathrm{kg}$ was recorded in the residual fraction at site 2 in warm and wet season. Though Fe is not toxic heavy metals, it analysis in the present study indicates its predominance of all the metal in all sites. Since the Fe concentration is very high in the residual fraction, the residual fraction could be converted to reducible fraction by the activity of plant roots, hence, available for plant uptake [40].

The behaviour of Mn was quite different from other metals in that percentage fractions were mainly associated with the exchangeable fraction of the soil samples (site 1) ranging from $0.20-13.52 \mathrm{mg} / \mathrm{kg}$ (Table 21). Availability of $\mathrm{Mn}$ in soils pose no threat to the plants especially at low concentrations recorded in the study.

As shown in Table 22, $\mathrm{Ni}$ across the sites was dominant in the residual fraction across the seasons (4.62 $115.70 \mathrm{mg} / \mathrm{kg}$ ). Highest concentration in the residual of $\mathrm{Cr}$ was obtained in site $5 \mathrm{in}$ cool and dry season, then in the Fe-MnO fraction (2.40 - 6.71 mg/kg).Residual, Fe-MnO and organic bound fraction is the predominant form 
of $\mathrm{Ni}$ in all the samples in the cool and dry season. $1.31-7.36$ and $0.66-7.64 \mathrm{mg} / \mathrm{kg}$ is in the exchangeable and carbonate fractions, respectively which can cause environmental toxicity during mobility [41]. Similar to this study, [41] showed that $\mathrm{Ni}$ in soils was concentrated in residual fractions. However, in this study, toxicity of Ni is not important because of its low concentration in the mobile and bioavailable fractions.

Highest concentration in residual of $\mathrm{Pb}$ was obtained in site 1 during the cool and dry season, then in the Fe-MnO fraction (2.49 - $5.14 \mathrm{mg} / \mathrm{kg})$ as shown in Table 23. Furthermore, with the exception of cool and dry season, lowest level of $\mathrm{Pb}$ was observed in the organic bound fraction. From the results, $\mathrm{Pb}$ in the soils was found at concentration range of $148.20-149.80 \mathrm{mg} / \mathrm{kg}$ in residual fraction during the cool and dry season across the sites, while, smaller amount was bound to water soluble and $\mathrm{Fe}-\mathrm{MnO}$ fraction. A similar distribution of $\mathrm{Pb}$ forms among fractions was reported for the fluvial deposits by [42].

As for Zn, significant amounts of the metal were associated with the residual fraction (Table 24) especially in cool and dry, however, in hot and dry season, highest concentration of $\mathrm{Zn}$ was associated with organic bound fraction (100.95 mg/kg). In warm and dry season, the dominant fraction across the sites was Fe-MnO (155.16 $155.83 \mathrm{mg} / \mathrm{kg}$ ). Higher concentration of $\mathrm{Zn}$ in Fe-MnO fraction can be attributed to diffusion mechanism [43]. This metal can be release into the environment under extremely reducible conditions [34].

\section{Conclusions}

1) The physicochemical parameters of the soils across the sites indicated values reported for less polluted soils.

2) With the exception of Cd, all metals evaluated in this study were lower than recommended standard limits.

3) The results of sequential extraction of heavy metal in soil sample indicated that all metals were mainly associated with the residual, Fe-MnO and organic bound fractions. The residual fraction had the maximum concentration of metals especially in cool and dry season for $\mathrm{Cr}, \mathrm{Cu}, \mathrm{Ni}, \mathrm{Pb}$ and $\mathrm{Zn}$, whereas only a small fraction of all the heavy metal was extracted in water soluble, exchangeable and carbonate bound fractions. It indicated that the bioavailability index was low. Hence, mobility of the heavy metals by the surrounding plants grown on the soils was low.

\section{Acknowledgements}

The authors wish to acknowledge the effort of Mr. Ilu of Soil Chemistry Laboratory, Ahmadu Bello University, Zaria in the soil sample analyses.

\section{References}

[1] Fong, F., Seng, C., Azan, A. and Tahir, M. (2008) Possible Source and Pattern Distribution of Heavy Metals Content in Urban Soil at Kuala Terengganu Town Centre. The Malasian Journal of Analytical Sciences, 12, 458-467.

[2] Van, N. and Krivolutsky, L. (1996) Bioindicator Systems for Soil Pollution. Kluwer Academic Publishers, Dordrecht, $1-8$.

[3] Jia, L., Yonghua, L. and Yang, L. (2010) Heavy Metals in Soil and Crops of an Intensively Farmed Area: Case Study in Yucheng City, Shandong Province, China. International Journal of Environmental Research and Public Health, 7, 395-412. http://dx.doi.org/10.3390/ijerph7020395

[4] Misra, S. and Mani, D. (2009) Soil Pollution. S. B. Nangia APH Publishing Corporation, New Delhi, 29-59.

[5] Adeyeye, E.I. (2005) Trace Metals in Soils and Plants from Fadma Farms in Ekiti State, Nigeria. Bulletin of the Chemical Society of Ethiopia, 9, 23-34.

[6] Jauro, A.G., Udom, G.N. and Mustapha, S. (2006) Soil Fertility Status of Fadama Lands in the Northern and Central Zones of Plateau State, Nigeria. Journal of Environmental Sciences, 10, 35-44.

[7] Mustafa, S. and Nnalee, C.C. (2007) Fertility and Salinity/Sodicity Status of Some Fadama Soils in Jos Plateau State, Nigeria. Journal of Sustainable Development in Agriculture and Environmental, 3, 96-103.

[8] Kolawole, A., Scoones, I., Awogbade, M.O. and Voh, J.P. (Eds.) (1994) Strategies for the Sustainable Use of Fadama lands in Northern Nigeria. International Institute for Environment and Development (IIED) and Centre for Social and Economic Research (CSER), Ahmadu Bello University, Zari, 29-34.

[9] Awode, U.A., Uzairu, A., Balarabe, M.L., Harrison, G.F.S. and Okunola, O.J. (2008) Assesment of Peppers and Soils for Some Heavy Metals from Irrigated Farmlands on the Banks of River Challawa, Nigeria. Pakistan Journal of Nutri- 
tion, 7, 244-248. http://dx.doi.org/10.3923/pjn.2008.244.248

[10] Abdullahi, M.S., Uzairu, A., Okunola, O.J. and Balarabe, M.L. (2015) Risk Assessment of Metals in Irrigated Food Crops Grown along the Bank of Tungan Kawo Dam, Kontagora, Nigeria Journal of Applied Chemistry, 8, 53-59.

[11] Bamgbose, O., Arowolo, T.O.A. and Odukoya, O. (2000) Earthworms as Bio-Indicators of Metal Pollution in Dumpsites of Abeokuta, Nigeria. Revista de Biología Tropical, 48, 229-234.

[12] Finžgar, N., Tlustoś, P. and Leštan, D. (2007) Relationship of Soil Properties to Fractionation, Bioavailability and Mobility of Lead and Zinc in Soil. Plant Soil and Environment, 5, 225-238.

[13] Tessier, A., Campell, P.G.C. and Bisson, M. (1979) Sequential Extraction Procedure for the Speciation of Particulate Trace Metals. Analytical Chemistry, 51, 844-851. http://dx.doi.org/10.1021/ac50043a017

[14] Herdershot, W.H., Lalande, H. and Duguette, M. (1993) Soil Reaction and Exchangeable Acidity. In: Carter, M.R., Ed., Soil Sampling and Methods of Analysis for Canadian Society of Soil Science, Lewis, Boca Raton, 141-145.

[15] Walkley, A. and Black, I.A. (1934) An Examination of the Detjare Method for Determining Soil Organic Matter and a Proposed Modification of the Chromic Acid Titration. Soil Science, 37, 29-36. http://dx.doi.org/10.1097/00010694-193401000-00003

[16] Bougoucos, G.H. (1951) Determination of Particle Sizes. Soil Agron. J., 43, 434-438.

[17] Allen, S.E. (1974) Chemical Analysis of Ecological Materials. Backwell Scientific Publications, Oxford, 13-106.

[18] Buol, S.W., Southard, R.J., Graham, R.C. and McDaniel, P.A. (2003) Soil Genesis and Classification. Wiley Blackwell, New York.

[19] Boateng, E., Dowuona, G.N.N., Nude, P.M., Foli, G., Gyekye, P. and Jafaru, H.M. (2012) Geochemical Assessment of the Impact of Mine Tailings Reclamation on the Quality of Soils at Anglo Gold Concession, Obuasi, Ghana. Research Journal of Environmental and Earth Sciences, 4, 466-474.

[20] Oiganji, E., Igbadun, H.E., Ahmed, A. and Oliver, U.E. (2015) Implication of Bakolori Dam Irrigation Activities on Its Physical Resources. African Journal of Agricultural Research, 10, 690-696. http://dx.doi.org/10.5897/AJAR2014.9165

[21] Boulding J.R. (1994) Description and Sampling of Contaminated Soils: A Feild Guide. 2nd Edition, CRC Press, Boca Raton.

[22] Jones, M.I. and Wild, A. (1975) Soils of West African Savanna. The Maintenance and Improvement of Their Fertility. Commonwealth Bureau of the Soils Technical Communication of the Harpenden. No. 55, UK Commonwealth Agricultural Bureau (CAB), Farnham Royal, 246.

[23] Evans, L.J. (1989) Chemistry of Metal Retention by Soils. Environmental Science and Technology, 23, 1046-1056. http://dx.doi.org/10.1021/es00067a001

[24] Okunola, O.J., Uzairu, A., Gimba C.E. and Kagbu, J.A. (2011) Metal Inter-Relationship and Its Mobility in Samples Collected along Roadside Corridors of Kano Metropolis, Nigeria. Research Journal of Environmental Toxicology, 5, 336-347. http://dx.doi.org/10.3923/rjet.2011.336.347

[25] Babatunde, O.A. and Ajibola, V.O. (2009) Determination of Some Anions along the Profile of Irrigated Farm Soils. International Research Journal, 3, 101-106.

[26] Brandy, N.C. (1974) The Nature and Property of Soils. Macmillian, New York, 639.

[27] Utsev, J.T., Ajon, A.T. and Ugama, T.I. (2014) Irrigation Soil Analysis in River Katsina-Ala Catchment Areas of North Central Nigeria. International Journal of Engineering and Technology, 4, 387-393.

[28] Cichota, R.I., Vogeler, N.S., Bolan, B. and Scotter, D.R. (2004) Sulphate Leaching through Two Contrasting New Zealand Soils Supper Soils. 3rd Australian New Zealand Soils Conference, University of Sydney, 5-9 December 2004, 1-8. www.regional.org.au/au/asssi

[29] Fixen, P.E., Gelderman, R.H., Gerwing, J.R. and Farber, B.G. (1987) Calibration and Implementation of a Soil Cl-Test. Journal of Fertility, 4, 91-97.

[30] Mico, C., Peris, M., Sanchez, J. and Recatala, L. (2006) Heavy Metal Content of Agricultural Soils in a Mediterranean Semiarid Area: The Segura River Valley (Alicante, Spain). Spanish Journal of Agricultural Research, 4, 363-372. http://dx.doi.org/10.5424/sjar/2006044-213

[31] MAFF (Ministry of Agriculture, Fisheries and Food and Welch Office Agriculture Department) (1992) Code of Good Agriculture Practice for the Protection of Soil. Draft Consultation Document, MAFF, London.

[32] Gungshik, J.R., Lohdip, Y.N. and Bewarang, E.S. (2007) Speciation of Trace Metals in Top Soils in Jos Industrial Area. African Journal of Natural Sciences, 10, 15-19.

[33] Zhang, N. (1999) Advance of the Research on Heavy Metals in Soil Plant System. Advance in Environmental Science, 7, 30-33.

[34] Venkateswaran, P., Vellaichamy, S. and Palanivelu, K. (2007) Speciation of Heavy Metals in Electroplating Industry 
Sludge and Wastewater Residue Using Inductive Coupled Plasma. International Journal of Environmental Science and Technology, 4, 497-504. http://dx.doi.org/10.1007/BF03325986

[35] USEPA (1998) Toxicological Review of Hexavalent Chromium. Environmental Protection Agency.

[36] Coetzee, P.P. (1993) Determination of Speciation of Heavy Metals in Sediments of the Hortbees Port: Dam by Sequential Chemical Extraction. Water SA, 9, 291-300.

[37] Abu-Kukati, Y. (2001) Heavy Metal Distribution and Speciation in Sediments from Ziqlab Dam-Jordan. Geological Engineering, 25, 33-40.

[38] Lu, Y., Gong, Z., Zhang, G. and Wolfgang, B. (2003) Concentrations and Chemical Speciation of $\mathrm{Cu}, \mathrm{Zn}, \mathrm{Pb}$ and $\mathrm{Cr}$ of Urban Soils in Nanjing, China. Geoderma, 115, 101-111. http://dx.doi.org/10.1016/S0016-7061(03)00079-X

[39] Yuan, C., Shi, J., He, B., Liu, J., Liang, L. and Jiang, G. (2004) Speciation of Heavy Metals in Marine Sediments from the East China Sea by ICP-MS with Sequential Extraction. Environment International, 30, 769-783. http://dx.doi.org/10.1016/j.envint.2004.01.001

[40] Otte, M.L., Kearns, C.C. and Doyle, M.O. (1995) Accumulation of Arsenic and Zinc in the Rhizosphere of Wetland Plants. Bulletin of Environmental Contamination and Toxicology, 55, 154-161. http://dx.doi.org/10.1007/BF00212403

[41] Karbassi, A.R. and Shankar, R. (2005) Geochemistry of Two Sediment Cores from the West Coast of India. International Journal of Environmental Science and Technology, 1, 307-316. http://dx.doi.org/10.1007/BF03325847

[42] Sobczynski, T. and Siepak, J. (2001) Speciation of Heavy Metals in Bottom Sediments of Lakes in the Area of Wielkopolski National Park. Polish Journal of Environmental Studies, 10, 463-474.

[43] Backes, C.A., McLaren, R.G., Rate, A.W. and Swift, R.S. (1995) Kinetics of Cd and Co Desorption from Iron and Manganese Oxides. Soil Science Society of America Journal, 59, 778-785. http://dx.doi.org/10.2136/sssaj1995.03615995005900030021x

\section{Submit or recommend next manuscript to SCIRP and we will provide best service for you:}

Accepting pre-submission inquiries through Email, Facebook, LinkedIn, Twitter, etc.

A wide selection of journals (inclusive of 9 subjects, more than 200 journals)

Providing 24-hour high-quality service

User-friendly online submission system

Fair and swift peer-review system

Efficient typesetting and proofreading procedure

Display of the result of downloads and visits, as well as the number of cited articles

Maximum dissemination of your research work

Submit your manuscript at: http://papersubmission.scirp.org/ 